\title{
Late Calcium EDTA Rescues Hippocampal CA1 Neurons from Global Ischemia-Induced Death
}

\author{
Agata Calderone, Teresa Jover, ${ }^{\star}$ Toshihiro Mashiko, ${ }^{\star}$ Kyung-min Noh, Hidenobu Tanaka, ${ }^{\dagger}$ Michael V. L. Bennett, and \\ R. Suzanne Zukin \\ Department of Neuroscience, Albert Einstein College of Medicine, Bronx, New York 10461
}

Transient global ischemia induces a delayed rise in intracellular $\mathrm{Zn}^{2+}$, which may be mediated via glutamate receptor 2 (GluR2)-lacking AMPA receptors (AMPARs), and selective, delayed death of hippocampal CA1 neurons. The molecular mechanisms underlying $\mathrm{Zn}^{2+}$ toxicity in vivo are not well delineated. Here we show the striking finding that intraventricular injection of the high-affinity $\mathrm{Zn}^{2+}$ chelator calcium EDTA (CaEDTA) at $30 \mathrm{~min}$ before ischemia (early CaEDTA) or at 48-60 hr (late CaEDTA), but not 3-6 hr, after ischemia, afforded robust protection of CA1 neurons in $\sim 50 \%$ (late CaEDTA) to $75 \%$ (early CaEDTA) of animals. We also show that $\mathrm{Zn}^{2+}$ acts via temporally distinct mechanisms to promote neuronal death. Early CaEDTA attenuated ischemia-induced GluR2 mRNA and protein downregulation (and, by inference, formation of $\mathrm{Zn}^{2+}$-permeable AMPARs), the delayed rise in $\mathrm{Zn}^{2+}$, and neuronal death. These findings suggest that $\mathrm{Zn}^{2+}$ acts at step(s) upstream from GluR2 gene downregulation and implicate $\mathrm{Zn}^{2+}$ in transcriptional regulation and/or GluR2 mRNA stability. Early CaEDTA also blocked mitochondrial release of cytochrome $c$ and Smac/DIABLO (second mitochondria-derived activator of caspases/direct inhibitor of apoptosis protein-binding protein with low pI), caspase-3 activity (but not procaspase-3 cleavage), $\mathrm{p} 75^{\mathrm{NTR}}$ induction, and DNA fragmentation. These findings indicate that CaEDTA preserves the functional integrity of the mitochondrial outer membrane and arrests the caspase death cascade. Late injection of CaEDTA at a time when GluR2 is downregulated and caspase is activated inhibited the delayed rise in $\mathrm{Zn}^{2+}, \mathrm{p} 75^{\mathrm{NTR}}$ induction, DNA fragmentation, and cell death. The finding of neuroprotection by late CaEDTA administration has striking implications for intervention in the delayed neuronal death associated with global ischemia.

Key words: zinc; global ischemia; neuronal death; apoptosis; excitotoxicity; AMPA receptors; p75 ${ }^{\text {NTR }}$

\section{Introduction}

Under physiological conditions, $\mathrm{Zn}^{2+}$ serves as a neuronal signaling molecule and is colocalized with glutamate in presynaptic vesicles at a subset of excitatory synapses (Choi and Koh, 1998). $\mathrm{Zn}^{2+}$ is uniquely high in mossy fiber tracts of the hippocampus. The zinc transporter 3 (ZnT-3) is localized to synaptic vesicle membranes within mossy fiber boutons and mediates loading of vesicular $\mathrm{Zn}^{2+}$ (Palmiter et al., 1996). $\mathrm{Zn}^{2+}$ is coreleased with glutamate spontaneously and in an activity-dependent manner and achieves synaptic concentrations of 10-100 $\mu \mathrm{M}$ (Choi and Koh, 1998) (but see Kay, 2003). Synaptically released $\mathrm{Zn}^{2+}$ mod-

\footnotetext{
Received May 4, 2004; revised Sept. 15, 2004; accepted Sept. 16, 2004.

This work was supported by National Institutes of Health Grants NS20752 and NS46742 (R.S.Z.) and NS45287 (M.V.L.B.), an American Heart Association Development Award (T.J.), and the F. M. Kirby Program in Neuroprotection and Repair. M.V.L.B is the Sylvia and Robert S. Olnick Professor of Neuroscience. We thank Drs. Dennis W. Cho and Pablo E. Castillo and members of the Zukin laboratory for helpful comments on this manuscript, Roodland Regis and Judy Wong for technical assistance, and the Analytical Imaging Facility of the Albert Einstein College of Medicine (Michael Cammer, director). We remember and honor Hidenobu Tanaka for his scientific insight, creativity, technical acumen, and his warmth and sensitivity as a human being.

*T.J. and T.M. contributed equally to this work.

${ }^{\dagger}$ Deceased, 0ct. 13, 2002.

Correspondence should be addressed to Dr. R. Suzanne Zukin, Department of Neuroscience, Albert Einstein College of Medicine, 1300 Morris Park Avenue, Bronx NY 10461. E-mail: zukin@aecom.yu.edu.

A. Calderone's present address: Department Genetic Medicine, Weill Medical College of Cornell University, New York, NY 10021.

D0I:10.1523/JNEUROSCI.1713-04.2004

Copyright $\odot 2004$ Society for Neuroscience $\quad$ 0270-6474/04/249903-11\$15.00/0
}

ulates the activity of postsynaptic receptors. Whereas $\mathrm{Zn}^{2+}$ inhibits NMDA receptors (NMDARs) and $\mathrm{GABA}_{\mathrm{A}}$ receptors (Peters et al., 1987; Westbrook and Mayer, 1987; Christine and Choi, 1990), it potentiates AMPA receptors (AMPARs) (Rassendren et al., 1990; Bresink et al., 1996). $\mathrm{Zn}^{2+}$ enters neurons via voltagesensitive $\mathrm{Ca}^{2+}$ channels, NMDARs, glutamate receptor 2 (GluR2)-lacking AMPARs, and/or the $\mathrm{Na}^{+} / \mathrm{Zn}^{2+}$ antiporter (Choi and Koh, 1998). Of these, GluR2-lacking AMPARs exhibit highest permeability to $\mathrm{Zn}^{2+}$ (Sensi et al., 1999), but under physiological conditions are expressed at low density on distal dendrites of CA1/3 pyramidal neurons (Lerma et al., 1994; Toomim and Millington, 1998; Yin et al., 1999). Within neurons, $\mathrm{Zn}^{2+}$ exists as a functionally important component of metalloenzymes and zinc finger-containing transcription factors. Synaptically released $\mathrm{Zn}^{2+}$ may be essential for long-term potentiation induction at CA3 synapses (Lu et al., 2000; Vogt et al., 2000; Li et al., 2001). Accordingly, $\mathrm{Zn}^{2+}$-deficient rats, monkeys, and humans exhibit cognitive impairment (Henkin et al., 1975; Golub et al., 1995; Lu et al., 2000).

$\mathrm{Zn}^{2+}$ at high concentrations is a critical mediator of the neuronal death associated with global ischemia, seizures, traumatic brain injury, and other brain disorders (Choi and Koh, 1998; Weiss et al., 2000; Dineley et al., 2003; Zukin et al., 2004). Global ischemia elicits a delayed rise in $\mathrm{Zn}^{2+}$ in selectively vulnerable CA1 neurons, evident at late times after insult but before onset of 
cell death (Koh et al., 1996; Park et al., 2000). The membraneimpermeant metal chelator calcium EDTA (CaEDTA), administered before ischemia, blocks the rise in $\mathrm{Zn}^{2+}$ and protects CA1 neurons. Global ischemia induces suppression of GluR2 mRNA and protein and promotes expression of GluR2-lacking AMPARs on CA1 neurons (Pellegrini-Giampietro et al., 1997). Injurious stimuli promote $\mathrm{Zn}^{2+}$ influx into neurons via GluR2-lacking AMPARs (Yin et al., 2002) and/or release of $\mathrm{Zn}^{2+}$ from intracellular stores (Aizenman et al., 2000; Lee et al., 2000).

Although the importance of $\mathrm{Zn}^{2+}$ to ischemic death is well established, the mechanisms underlying $\mathrm{Zn}^{2+}$ toxicity in vivo are less clear. The present study was undertaken to address these mechanisms and examine whether CaEDTA administered after ischemia can rescue CA1 neurons. EDTA exhibits higher affinity for $\mathrm{Zn}^{2+}$ than $\mathrm{Ca}^{2+}$; CaEDTA effectively chelates $\mathrm{Zn}^{2+}$, replacing it with equimolar $\mathrm{Ca}^{2+}$ (Koh et al., 1996). Here we show that CaEDTA rescues CA1 neurons when administered as late as $60 \mathrm{hr}$ after ischemia. Early CaEDTA attenuates mitochondrial release of cytochrome $c$ and Smac/DIABLO (second mitochondriaderived activator of caspases/direct inhibitor of apoptosis protein-binding protein with low $\mathrm{pI}$ ), caspase-3 activity (but not procaspase-3 cleavage), and GluR2 downregulation. Late CaEDTA blocks the rise in $\mathrm{Zn}^{2+}, \mathrm{p} 75^{\mathrm{NTR}}$ expression, and DNA fragmentation. Thus, $\mathrm{Zn}^{2+}$ acts via temporally distinct mechanisms to promote ischemic cell death.

\section{Materials and Methods}

Animals. Age-matched adult male Mongolian gerbils weighing 60-80 gm (Tumblebrook Farms, Wilmington, MA) and male Sprague Dawley rats weighing 100-150 gm (Charles River, Wilmington, DE) were maintained in a temperature- and light-controlled environment with a 14/10 $\mathrm{hr}$ light/dark cycle and were treated in accordance with the principles and procedures of the National Institutes of Health Guidelines for the Care and Use of Laboratory Animals. Protocols were approved by the Institutional Animal Care and Use Committee of the Albert Einstein College of Medicine.

CaEDTA administration. Animals were administered CaEDTA (300 mM in $5 \mu$ l of saline; $\mathrm{CaNa}_{2}$ EDTA; Sigma, St. Louis, $\mathrm{MO}$ ) or saline only $(5 \mu \mathrm{l})$ by a single unilateral injection into the right lateral ventricle at a flow rate of $1 \mu \mathrm{l} / \mathrm{min}$ at $30 \mathrm{~min}$ before or at indicated times after global ischemia or sham surgery. EDTA is a broad-spectrum divalent-cation chelator that binds $\mathrm{Zn}^{2+}$ with higher affinity than $\mathrm{Ca}^{2+}$ (Bers et al., 1994); CaEDTA chelates $\mathrm{Zn}^{2+}$ and replaces it with equimolar $\mathrm{Ca}^{2+}$ (Dawson et al., 1984; Koh et al., 1996). Although CaEDTA chelates other metals such as $\mathrm{Fe}^{2+}$ and $\mathrm{Cu}^{2+}$, they do not appear causally related to ischemic cell death, nor does ZnEDTA block $\mathrm{Fe}^{2+}$ or $\mathrm{Cu}^{2+}$ neurotoxicity (Koh et al., 1996). For intracerebroventricular injections, animals were positioned in a stereotaxic frame, and a cannula (28 gauge; stainless steel; inner diameter, $0.18 \mathrm{~mm}$; outer diameter, $0.36 \mathrm{~mm}$ ) was lowered stereotaxically into the right cerebral ventricle to a position defined by the following coordinates: $0.92 \mathrm{~mm}$ posterior to bregma, $1.2 \mathrm{~mm}$ lateral to bregma, $3.6 \mathrm{~mm}$ below the skull surface (rats) or $0.4 \mathrm{~mm}$ posterior to bregma, $1.2 \mathrm{~mm}$ lateral to bregma, $2.6 \mathrm{~mm}$ below the skull surface (gerbils).

Global ischemia. All experiments except cytochrome $c$ and Smac/ DIABLO immunolabeling and caspase activity were performed in gerbils. Gerbils offer an advantage compared with rats in that global ischemia can be produced by the relatively simple procedure, bilateral occlusion of the carotid arteries (BCCO). The day before surgery, CaEDTA- and saline-injected animals were fasted overnight and anesthetized with halothane ( $4 \%$ for the first $5 \mathrm{~min}$, followed by $1 \%$ for maintenance) delivered by mask in a mixture of $\mathrm{N}_{2}-\mathrm{O}_{2}$ (70:30) by means of a Vapomatic anesthetic vaporizer (CWE, Ardmore, PA). Gerbils were subjected to global ischemia by temporary BCCO $(5 \mathrm{~min})$ or to sham operation followed by reperfusion, as described previously (Oguro et al., 1999; Opitz et al., 2000). Global ischemia in rats was as described previ- ously (Calderone et al., 2003). In all cases, anesthesia was discontinued immediately after initiation of occlusion. Body temperature was monitored and maintained at $37.5 \pm 0.5^{\circ} \mathrm{C}$ with a rectal thermistor and heat lamp until recovery from anesthesia. Animals that failed to show complete loss of the righting reflex and dilation of the pupils from $2 \mathrm{~min}$ after occlusion was initiated until the end of occlusion, and the rare animals that exhibited obvious behavioral manifestations (abnormal vocalization when handled, generalized convulsions, hypoactivity) or loss of $>20 \%$ body weight by 3-7 d were excluded from the study. After reperfusion, arteries were visually inspected to ensure adequate reflow.

$\mathrm{Zn}^{2+}$ staining. To measure intracellular free $\mathrm{Zn}^{2+}$ concentrations in neurons, brain sections were labeled with the $\mathrm{Zn}^{2+}$-selective fluorescent quinoline derivative $\mathrm{N}$-6-(methoxy-8-quinolyl)-para-toluenesulfonamide (TSQ) (Frederickson et al., 1987). Fresh-frozen coronal brain sections (18 $\mu \mathrm{m}$ ) were thawed, air dried, labeled with TSQ $(0.01 \%)$, and washed (once in PBS, followed by once in distilled water). Images were viewed under a Nikon (Tokyo, Japan) Eclipse TE300 fluorescence microscope and acquired with a SPOT RT CCD-cooled camera equipped with Diagnostic Software version 3.0. Settings were held constant for imaging of all sections.

Histological analysis. Neuronal cell loss was assessed by histological examination of toluidine blue-stained brain sections at the level of dorsal hippocampus from animals killed at $72 \mathrm{hr}, 5$, and $7 \mathrm{~d}$ after ischemia or sham operation, as described previously (Calderone et al., 2003). Animals were deeply anesthetized with pentobarbital (50 mg/kg, i.p.) and fixed by transcardiac perfusion with ice-cold $4 \%$ paraformaldehyde in PBS (0.1 $\mathrm{M}, \mathrm{pH} 7.4)$. Brains were removed and immersed in fixative $\left(4^{\circ} \mathrm{C}\right.$ overnight). Coronal sections $(15 \mu \mathrm{m})$ were cut at the level of the dorsal hippocampus with a cryotome and stained with toluidine blue. For Figure $2, a-p$, the number of surviving pyramidal neurons per $250 \mu \mathrm{m}$ length of the medial CA1 region from six to eight gerbils per group (four sections per gerbil) was counted under a light microscope at $40 \times$ magnification in sections. For Figure 2q, neuronal damage in the left and right hippocampus was scored on a scale of $0-3$ (in which 0 is no damage and 3 is maximal damage) according to Pulsinelli and Brierely (1979). Statistical analysis was assessed by ANOVA, followed by Scheffe's post hoc tests.

GluR2 in situ hybridization. A [ $\left.{ }^{35} \mathrm{~S}\right] \mathrm{UTP}-$ labeled RNA probe directed to the GluR2 mRNA was transcribed in vitro using a commercially available kit (Stratagene, La Jolla, CA), as described previously (Calderone et al., 2003). mRNA expression was assessed by in situ hybridization on coronal sections of brain at the level of the hippocampus from experimental and control animals at $48,72 \mathrm{hr}$, and $5 \mathrm{~d}$ after surgery (Calderone et al., 2003). In brief, brains were rapidly removed, frozen by immersion in 2-methylbutane at $-42^{\circ} \mathrm{C}$, and stored at $-70^{\circ} \mathrm{C}$ until use. Coronal sections $(18 \mu \mathrm{m})$ were cut by cryotome and thaw mounted onto glass slides. For in situ hybridization, brain sections were acetylated, incubated with prehybridization solution $\left(2 \mathrm{hr}\right.$ at $\left.50^{\circ} \mathrm{C}\right)$, and hybridized with ${ }^{35} \mathrm{~S}$ labeled GluR1 or GluR2 RNA probes $\left(1 \mathrm{ng} / \mu \mathrm{l}\right.$ or $10^{6} \mathrm{cpm} /$ section; overnight at $\left.49^{\circ} \mathrm{C}\right)$. Sections were washed, treated with RNase A $(20 \mu \mathrm{g} / \mathrm{ml} ; 30$ $\mathrm{min}$ at room temperature), dehydrated by immersion in graded ethanol solutions, and apposed to Kodak XAR-5 film (Eastman Kodak, Rochester, NY) for 3-4 d. For quantitation of mRNA expression, autoradiograms were analyzed with a Scan Jet 4 -C computing densitometer using NIH Image 1.61 image-analysis software, as described previously (Calderone et al., 2003).

Western blot analysis. To assess GluR2 protein abundance, protein samples were isolated from microdissected hippocampal subfields of experimental and control animals $(n=3-5)$ at 48 and $72 \mathrm{hr}$ after reperfusion and subjected to Western blot analysis, as described previously (Calderone et al., 2003). In brief, animals were deeply anesthetized and killed by decapitation at 24,48 , and $72 \mathrm{hr}$ after ischemia or sham operation. Hippocampi were rapidly dissected out, and transverse slices of dorsal hippocampus $(1 \mathrm{~mm})$ were cut with a Mcllwain tissue chopper. The CA1 and dentate gyrus containing the hilus and CA3c (hereafter termed dentate gyrus) were rapidly microdissected, placed in ice-cold PBS supplemented with the protease inhibitor phenylmethylsulfonyl fluoride (PMSF) ( $1 \mathrm{~mm}$; Sigma), and stored at $-70^{\circ} \mathrm{C}$ until use. Tissue samples were homogenized by sonication in $200 \mu \mathrm{l}$ of $1 \mathrm{mM} \mathrm{Na}_{2} \mathrm{CO}_{3}$ buffer, $\mathrm{pH}$ 6.8 , containing PMSF, and lysed in Laemmli sample buffer $(0.025 \mathrm{M}$ Tris-HCI, 5\% glycerol, $1 \%$ SDS, $0.5 \%$ PBS, $0.1 \mathrm{~m}$ dithiothreitol, $2.5 \mathrm{~mm}$ 
$\beta$-mercaptoethanol, 1 mм PMSF, $0.5 \mathrm{~mm} \mathrm{NaHNO}_{3}$ buffer, $\mathrm{pH}$ 6.8). Protein concentration of samples was measured using the BCA protein assay kit (Pierce, Rockford, IL). Protein samples $(10 \mu \mathrm{g})$ were separated by gel electrophoresis (10\% polyacrylamide mini-gels; Bio-Rad, Richmond, $\mathrm{CA})$ and transferred to nitrocellulose membranes for immunolabeling. After reaction, membranes were treated with ECL reagents (Amersham Life Science, Arlington Heights, IL) and apposed to XAR-5 x-ray film (Eastman Kodak). Membranes were reprobed for $\beta$-actin as a loading control.

To quantitate protein abundance, bands on Western blots were analyzed with a Scan Jet 4-C computing densitometer using NIH Image 1.61 software. Bands of samples from experimental animals were normalized to $\beta$-actin (as a loading control) and expressed as a percentage of the corresponding control value. Protein standard curves were constructed to ensure that samples were in the linear range.

Caspase activity assay. Caspase assays were performed on sections of fresh-frozen rat brain using the FAM-DEVD-FMK caspase detection kit according to manufacturer's instructions (APO LOGIXTM) (Tanaka et al., 2004). FAM-DEVD-FMK is a carboxy-fluorescein analog of benzyloxycarbonyl-Asp(OMe)-Glu(OMe)-Val-Asp(OMe)-

fluoromethylketone (zDEVD-FMK), a broad-spectrum cysteine protease inhibitor that enters cells and irreversibly binds activated caspases. FAM-DEVD-FMK exhibits higher affinity for caspase-3 than for caspase- 8 or caspase- 7 and exhibits much lower affinity for the calpains than for caspases; thus, at $5 \mu \mathrm{M}$, FAM-DEVD is a relatively selective inhibitor of caspase-3 (Pozarowski et al., 2003). Moreover, FAM-DEVDFMK labeling of CA1 neurons correlates well with caspase- 3 activation, as assessed by Western blot analysis (Tanaka et al. 2004). In this study, we therefore refer to FAM-DEVD-FMK labeling as indicative of caspase-3 activity. Brain sections were labeled with $5 \mu \mathrm{M}$ FAM-DEVD-FMK ( $1 \mathrm{hr}$; $37^{\circ} \mathrm{C}$ ), washed three times, and viewed under a Nikon Eclipse TE-300 fluorescent microscope equipped with an image analysis system at an excitation wavelength of $488 \mathrm{~nm}$ and emission wavelength of $565 \mathrm{~nm}$. Images were acquired with a SPOT RT CCD-cooled camera with Diagnostic Software version 3.0. For quantitation of caspase-3 activity, images were analyzed by NIH Image 1.61 software. Statistical analysis was by ANOVA and Newman-Keuls test.

Detection of DNA cleavage and $p 75^{N T R}$. DNA fragmentation and p $75^{\text {NTR }}$ were detected in neurons by terminal deoxynucleotidyl transferase-mediated dUTP nick end labeling (TUNEL)-p $75^{\text {NTR }}$ Hoechst 33342 triple labeling of fresh-frozen brain sections from control and experimental gerbils at $72 \mathrm{hr}$ after ischemia using an in situ cell death detection kit (Roche Molecular Biochemicals, Mannheim, Germany), as described previously (Jover et al., 2002). In brief, sections were fixed in $4 \%$ paraformaldehyde for $20 \mathrm{~min}$ at $4^{\circ} \mathrm{C}$ and processed for TUNEL. Sections were then blocked and labeled with an anti-p $75^{\text {NTR }}$ antibody, followed by biotinylated goat anti-rabbit $\operatorname{IgG}(1: 200)$ and avidinconjugated Texas Red (1:200; Vector Laboratories, Burlingame, CA). During washes, sections were labeled with the nuclear stain Hoechst 33342 according to manufacturer's instructions (Molecular Probes, Eugene OR). Images were viewed under a Nikon Eclipse TE300 fluorescence microscope and acquired with a SPOT RT CCD-cooled camera equipped with Diagnostic Software version 3.0. Settings were held constant for imaging of sections from control and experimental animals. TUNELpositive cells were identified directly by the fluorescence signal of incorporated fluorescein-dUTP.

Antibodies. The following antibodies were used in this study: (1) a monoclonal antibody directed to a sequence within the N-terminal domain of the GluR2 subunit (1:1000; PharMingen, San Diego, CA); (2) rabbit anti-p $75^{\text {NTR }}$ polyclonal antibody directed to the cytoplasmic domain of human $75^{\text {NTR }}$ (1:4000; gift from Dr. Moses V. Chao, New York University School of Medicine, New York, NY); (3) anti-cytochrome $c$ mouse monoclonal antibody raised against peptides 1-80, 81-104, and 66-104 of pigeon cytochrome $c(1.5 \mu \mathrm{g} / \mathrm{ml}$; clone 7H8.2C12; PharMingen); (4) anti-Smac/DIABLO antibody, raised against a synthetic peptide corresponding to amino acid residues 222-237 of murine Smac/DIABLO $(0.5 \mu \mathrm{g} / \mathrm{ml}$; Axxora, San Diego, CA); and (5) anti-caspase-3p20, a goat polyclonal antibody that recognizes both procaspase- 3 and activated caspase-3 (1:75; Santa Cruz Biotechnology, Santa Cruz, CA). Secondary antibodies were HRP-conjugated rabbit anti-goat IgG (1:2000; Vector Laboratories) for caspase-3, biotinylated goat anti-rabbit IgG (1:200; Vector Laboratories) for $\mathrm{p} 75^{\mathrm{NTR}}$, or HRP-conjugated horse anti-mouse IgG (1:2000; Vector Laboratories) for GluR2, cytochrome $c$, and Smac/DIABLO.

\section{Results \\ The rise in $\mathrm{Zn}^{2+}$ in selectively vulnerable CA1 neurons is highly delayed}

Considerable evidence indicates that global ischemia elicits a rise in $\mathrm{Zn}^{2+}$ in selectively vulnerable CA1 neurons and that $\mathrm{Zn}^{2+}$ is a mediator of neuronal death (Choi and Koh, 1998; Weiss et al., 2000; Koh, 2001; Dineley et al., 2003). However, the time course of $\mathrm{Zn}^{2+}$ accumulation in CA1 neurons is not well delineated. To address this issue, we assessed levels of intracellular $\mathrm{Zn}^{2+}$ in hippocampal neurons with the $\mathrm{Zn}^{2+}$-specific fluorescence indicator dye TSQ at times after ischemia. In control hippocampus, TSQ labeling revealed intense fluorescence in the mossy fiber axons of dentate granule neurons in the hilus and stratum lucidum of $\mathrm{CA} 3$, as well as faint fluorescence in the stratum radiatum and stratum oriens of CA1 (Fig. $1 a, b) . \mathrm{Zn}^{2+}$ was not detectable in the pyramidal cell layer of CA1 or CA3. At 0 and $1 \mathrm{hr}$ after ischemia, the pattern and intensity of TSQ staining did not differ detectably from that observed in control hippocampus (data not shown). Global ischemia induced a slight reduction in $\mathrm{Zn}^{2+}$ fluorescence in mossy fibers and Schaffer collaterals, evident at $24 \mathrm{hr}$ after reperfusion, and bright fluorescence in the cell bodies of scattered hilar neurons (Fig. 1e,f). At $48 \mathrm{hr}$ after ischemia, $\mathrm{Zn}^{2+}$ was visible in pyramidal neurons of the CA3a, extending into the CA1/CA3 transition zone, but not CA1 (Fig. $1 g, h$ ). At $72 \mathrm{hr}$ after ischemia, $\mathrm{Zn}^{2+}$ fluorescence was pronounced in cell bodies of CA1 pyramidal neurons (Fig. 1 $i, j$ ). These findings indicate a substantial delay (nearly $72 \mathrm{hr}$ ) between ischemic insult and $\mathrm{Zn}^{2+}$ accumulation in selectively vulnerable neurons. This late rise in $\mathrm{Zn}^{2+}$ is thought to occur via GluR2-lacking AMPARs, which are highly permeable to $\mathrm{Zn}^{2+}$ (Sensi et al., 1999; Yin et al., 2002) and exhibit enhanced expression in CA1 neurons at 60-72 hr after ischemia (Gorter et al., 1997).

EDTA is a broad-spectrum divalent-cation chelator that binds $\mathrm{Zn}^{2+}$ with higher affinity than $\mathrm{Ca}^{2+}$; CaEDTA chelates $\mathrm{Zn}^{2+}$ and replaces it with equimolar $\mathrm{Ca}^{2+}$ (Dawson et al., 1984; Bers et al., 1994). Although CaEDTA chelates other metals such as $\mathrm{Fe}^{2+}$ and $\mathrm{Cu}^{2+}$, they do not appear causally related to ischemic cell death, nor does ZnEDTA block $\mathrm{Fe}^{2+}$ or $\mathrm{Cu}^{2+}$ neurotoxicity (Koh et al., 1996). Administration of CaEDTA 30 min before ischemia (early CaEDTA) did not detectably alter the rise in $\mathrm{Zn}^{2+}$ in the CA3a or transition zone, evident at $48 \mathrm{hr}$ (data not shown) but markedly attenuated the late rise in $\mathrm{Zn}^{2+}$ in CA1 neurons at $72 \mathrm{hr}$ (Fig. $1 k, l)$, in confirmation of findings in rats (Koh et al., 1996). In contrast, administration of CaEDTA $(300 \mathrm{~mm})$ into the lateral ventricles of control animals did not detectably alter the pattern or intensity of $\mathrm{Zn}^{2+}$ fluorescence in hippocampus, assessed at 72 hr after sham operation (Fig. $1 c, d$ ).

\section{Early and late injections of CaEDTA protect against ischemia- induced death of CA1 neurons}

If $\mathrm{Zn}^{2+}$ indeed accumulates in CA1 neurons at $48-72 \mathrm{hr}$ after ischemia, CaEDTA might be protective not only if given before ischemia, but also when administered as late as $48-60 \mathrm{hr}$ after ischemia (late CaEDTA). To examine the time window in which CaEDTA was effective, we subjected gerbils to global ischemia or sham operation and administered CaEDTA (300 mM, i.c.v.) at times before or after surgery; neuronal death was assessed histologically. As expected, 

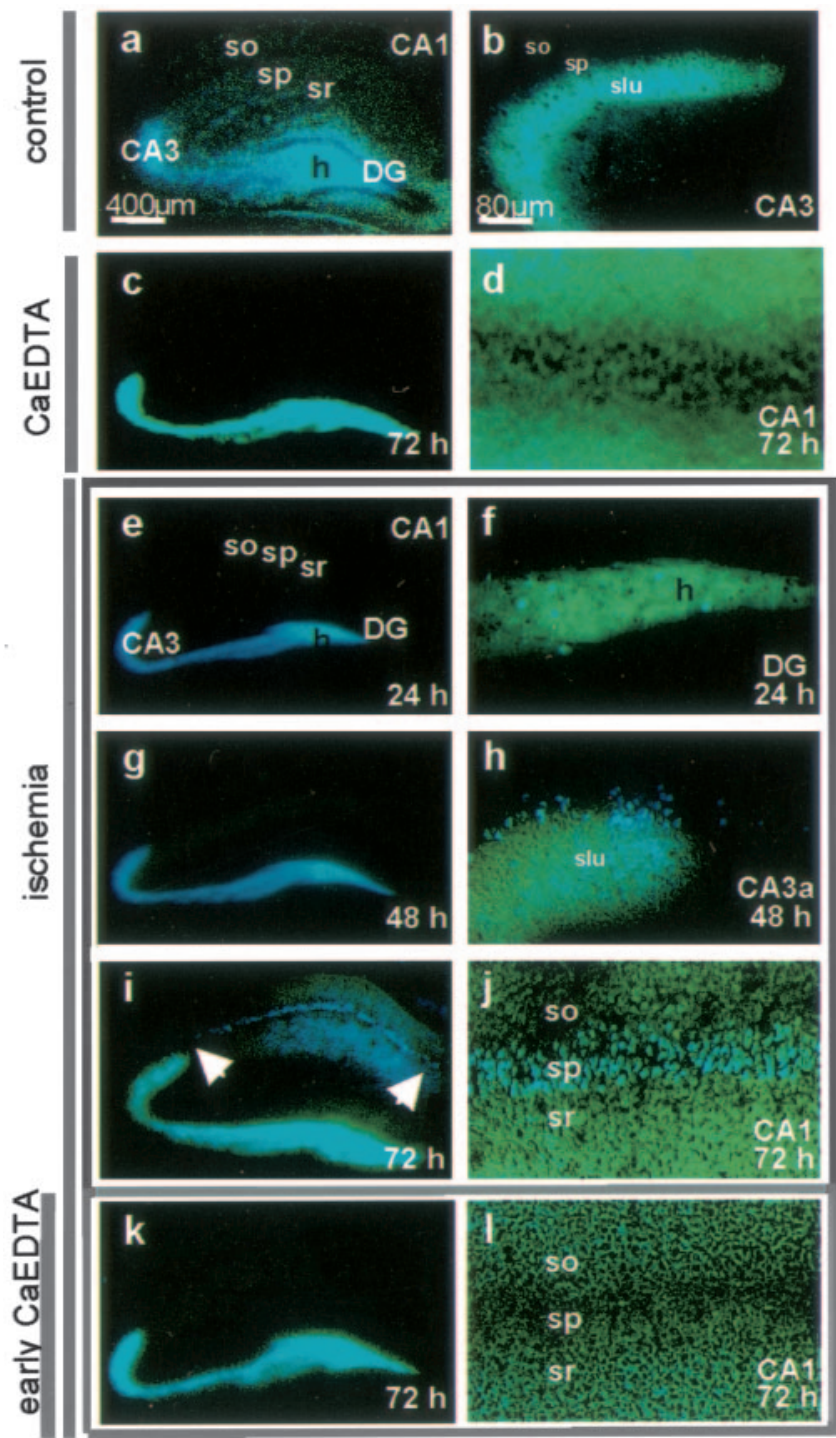

Figure 1. Global ischemia elicits a highly delayed rise in $\mathrm{Zn}^{2+}$ in selectively vulnerable CA1 neurons. $Z \mathrm{Zn}^{2+}$ fluorescence in TSQ-stained coronal brain sections from sham $(a-d)$ and experimental animals subjected to global ischemia (e-l) or to CaEDTA, followed by global ischemia $(k, I)$. In control hippocampus, TSQ labeling revealed intense fluorescence in the mossy fiber axon terminals of dentate granule neurons in the hilus ( $h$ ) and stratum lucidum of $\mathrm{CA} 3$ (slu) and faint fluorescence in the stratum radiatum and stratum oriens of $\mathrm{CA} 1(a, b)$. CaEDTA injection at $30 \mathrm{~min}$ before surgery did not detectably alter the pattern of $\mathrm{Zn}^{2+}$ fluorescence in shamoperated control animals, assessed at $72 \mathrm{hr}$ after surgery $(c, d)$. Global ischemia induced a pronounced increase in $\mathrm{Zn}^{2+}$ fluorescence in the cell bodies of scattered hilar neurons, evident at $24 \mathrm{hr}$ after insult $(e, f)$. At $48 \mathrm{hr}, \mathrm{Zn}^{2+}$ fluorescence was visible in CA3a pyramidal neurons, extending into the CA1/CA3 transition zone, but was not visible in CA1 $(g, h)$. At $72 \mathrm{hr}, \mathrm{Zn}^{2+}$ fluorescence was pronounced in cell bodies of CA1 pyramidal neurons $[i$ (arrows), $j]$. Injection of CaEDTA 30 min before ischemia did not affect the increase in $\mathrm{Zn}^{2+}$ in the transition zone but attenuated the late rise in $\mathrm{Zn}^{2+}$ fluorescence in the $\mathrm{CA} 1(k, l)$. Scale bars: (in $\left.a\right) a, c, e, g, i, k, 400$ $\mu \mathrm{m}$; (in $b) b, d, f, h, j, l, 80 \mu \mathrm{m}$. so, Stratum oriens; sp, stratum pyramidale; sr, stratum radiatum.

global ischemia induced extensive death of pyramidal cells in the hippocampal CA1, evident at $5 \mathrm{~d}$; the few remaining pyramidal neurons were severely damaged and appeared pyknotic $(93.0 \pm 1.45$ cells $/ 250 \mu \mathrm{m}$ in control animals; $2.1 \pm 1.45$ cells $/ 250 \mu \mathrm{m}$ in ischemic animals; $n=5 ; p<0.01$ vs control) (Fig. $2 e, f, o$ ). Neuronal death was specific in that little or no cell loss occurred in the nearby CA2 or transition zone, CA3, or dentate gyrus (Fig. 2e). With the exception of a few scattered hilar neurons and/or pyramidal neurons in the cortex, no other neurons exhibited cell death. Neuronal death was delayed in that little or no death was manifest at $72 \mathrm{hr}$ (data not shown) (but see Gorter et al., 1997). These data corroborate findings in rats (Calderone et al., 2003) and gerbils (Colbourne et al., 2003). CaEDTA administered $30 \mathrm{~min}$ before ischemia greatly reduced the loss of CA1 neurons (CaEDTA pretreatment, $63.44 \pm 5.49$ cells $/ 250$ $\mu \mathrm{m} ; n=5 ; p<0.01$ vs ischemia only) (Fig. $2 g, h, s$ ). In contrast, CaEDTA administered to control animals did not detectably alter neuronal counts (Fig. $2 c, d, s$ ). These findings are in confirmation of others (Koh et al., 1996) and are consistent with a model in which $\mathrm{Zn}^{2+}$ plays a role in early events leading to delayed death of CA1 neurons.

Administration of CaEDTA at $60 \mathrm{hr}$ after ischemic insult afforded substantial survival of CA1 neurons in $\sim 50 \%$ of animals, relative to that of saline-injected animals subjected to ischemia (saline, $14.9 \pm 3.4$ cells $/ 250 \mu \mathrm{m}, n=20, p<0.01$ vs control; CaEDTA at $60 \mathrm{hr}, 38.3 \pm 4.9$ cells $/ 250 \mu \mathrm{m}, n=25, p<0.01 \mathrm{vs}$ ischemia) (Fig. 2o-r,t). Similar results were observed when CaEDTA was given at $48 \mathrm{hr}$. In contrast, CaEDTA was ineffective when injected at $72 \mathrm{hr}$, a time when intracellular $\mathrm{Zn}^{2+}$ accumulation in CA1 neurons had already occurred (Fig. $2 u$ ), although the relatively low number of animals sampled precludes a definitive conclusion. These findings are consistent with the concept that CaEDTA administered at 48 or $60 \mathrm{hr}$ after global ischemia chelates extracellular $\mathrm{Zn}^{2+}$, preventing its influx via newly synthesized GluR2-lacking AMPARs, voltage-sensitive $\mathrm{Ca}^{2+}$ channels, and/or by reverse operation of the $\mathrm{Zn}^{2+}$ antiporter and can chelate intracellular $\mathrm{Zn}^{2+}$, which leaches out of neurons to restore the extracellular $\mathrm{Zn}^{2+}$ concentration (Frederickson et al., 2002). In contrast, CaEDTA administered at 3 or $6 \mathrm{hr}$ after ischemia did not afford significant protection (Fig. $2 u$ ). Thus, CaEDTA affords protection at temporally separated windows of time, consistent with a model in which $\mathrm{Zn}^{2+}$ acts via temporally distinct mechanisms to elicit neuronal death.

\section{Early CaEDTA attenuates ischemia-induced suppression of GluR2 mRNA in CA1 neurons}

The notion that $\mathrm{Zn}^{2+}$ acts at an early time after ischemic insult is consistent with a role in transcriptional changes, which occur at early times after ischemia. Global ischemia activates the restrictive element-1 silencing transcription factor (REST)-neuronrestrictive silencer factor (Calderone et al., 2003), a nine zinc finger transcription factor that suppresses neural-specific target genes including GluR2 (Huang et al., 1999, 2002; Brene et al., 2000; Calderone et al., 2003). Although it is not known how ischemia-hypoxia triggers induction of REST, an attractive hypothesis is that the early rise in calcium during the ischemic episode triggers a calcium-responsive transcription factor, which in turn induces REST expression. To examine a role for $\mathrm{Zn}^{2+}$ in the transcriptional changes associated with global ischemia, we administered the $\mathrm{Zn}^{2+}$ chelator CaEDTA or saline to gerbils $30 \mathrm{~min}$ before global ischemia or sham operation and measured AMPAR mRNA expression in CA1 neurons by in situ hybridization at times after reperfusion. In control hippocampus, GluR2 mRNA expression was pronounced throughout the pyramidal cell layers of CA1 and CA3 and the granule cell layer of the dentate gyrus (Fig. 3a). Global ischemia induced a marked and long-lasting reduction in GluR2 mRNA expression in the pyramidal cell layer of CA1, evident at 48 and $72 \mathrm{hr}$ (reduction to $41.2 \% \pm 0.5 \%$ of control at $48 \mathrm{hr}, n=3, p<0.01$; to $22.1 \pm 2 \%$ of control at $72 \mathrm{hr}$, $n=4, p<0.01$ ) (Fig. 3a,c), times before the onset of neuronal death (Fig. 2). At $5 \mathrm{~d}$, a time when there is extensive cell loss in the CA1 pyramidal cell layer, GluR2 mRNA was reduced to $19.4 \pm$ 

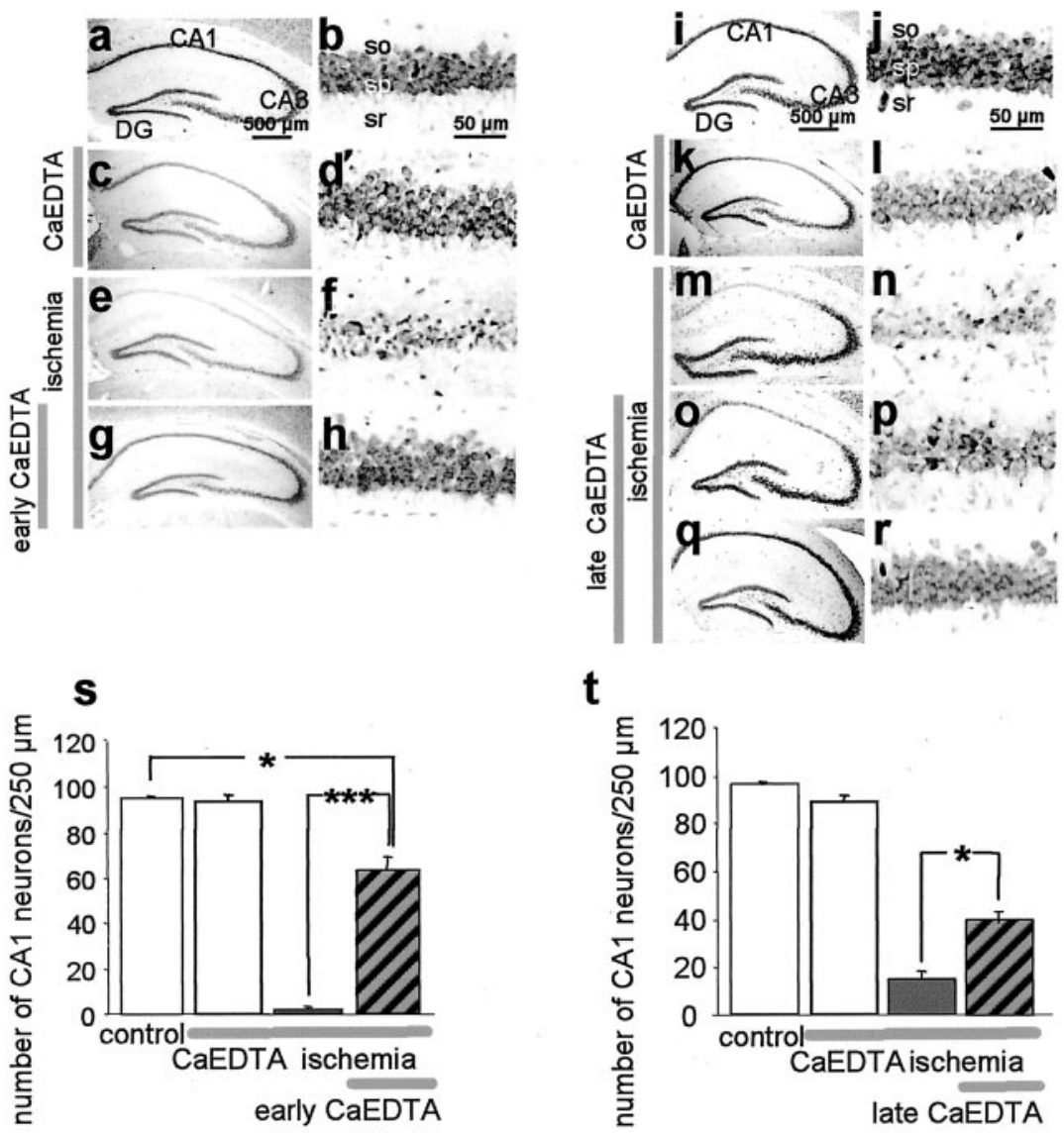

t
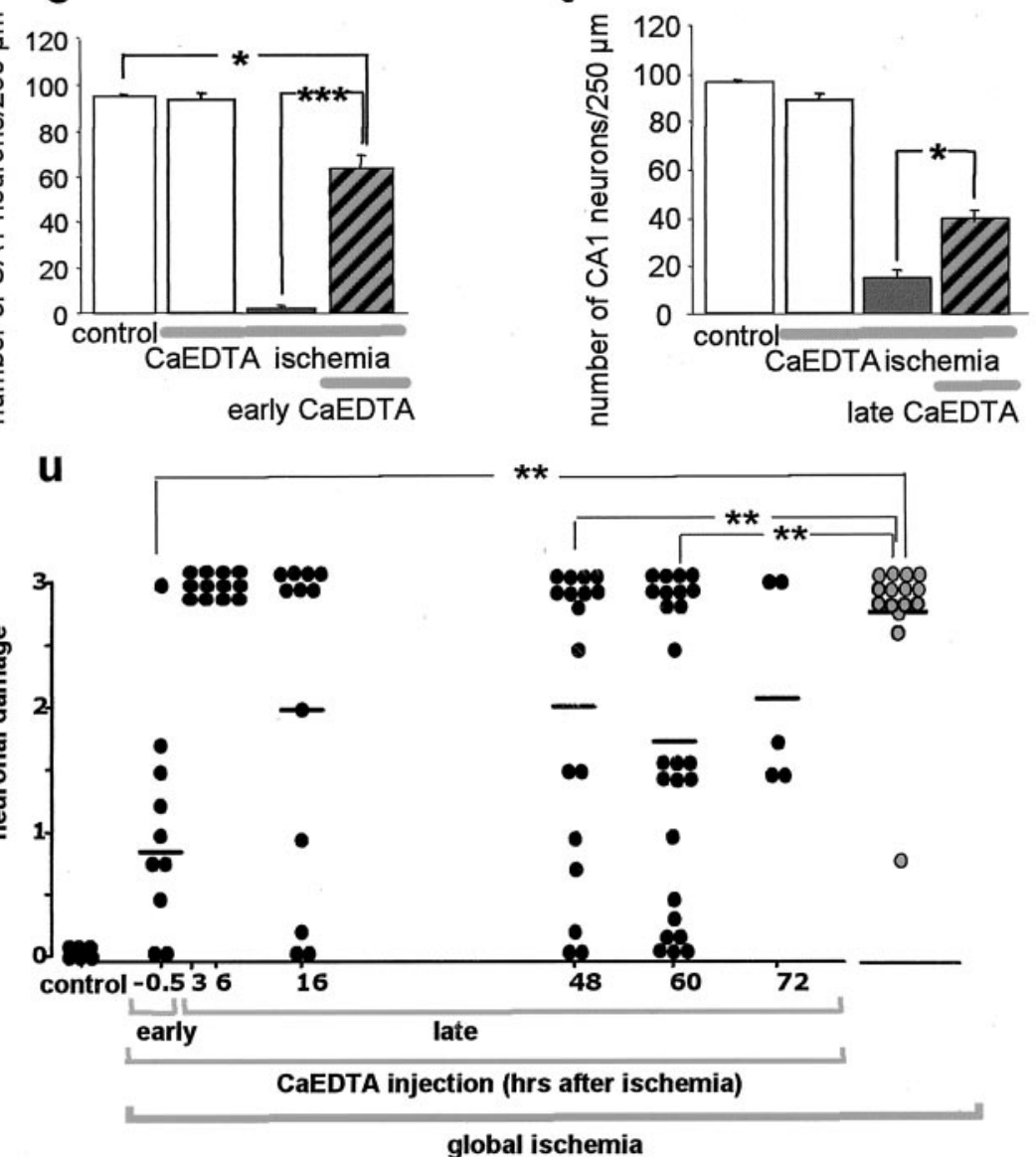

Figure 2. Early and late CaEDTA afford protection against ischemia-induced neuronal death. Toluidine blue-stained coronal brain sections at the level of the dorsal hippocampus from control $(n=3 ; a, b)$ and experimental animals subjected to CaEDTA injection $(c, d)$, global ischemia $(e, f)$, or to CaEDTA ( $300 \mathrm{~mm}$, i.c.v.), followed by ischemia $(g, h)$ and killed $5 \mathrm{~d}$ after surgery. Brain sections from sham $(n=3 ; i, j)$ and experimental animals subjected to CaEDTA injection $(k, I)$, ischemia $(n=4 ; m, n)$, or to ischemia, followed by CaEDTA at $60 \mathrm{hr}$ after ischemia $(n=6 ; 0-r)$ and killed $7 \mathrm{~d}$ after ischemia. Late CaEDTA afforded robust neuroprotection is some $(q, r)$, but not other $(0, p)$, animals. $s, t$, Quantitation of cell counts from sections such as those shown in $a-h(s)$ and $i-r(t) . u$, Summary data for CaEDTA injections given at times ranging from $30 \mathrm{~min}$ before ischemia to $72 \mathrm{hr}$ after ischemia. Global ischemia was induced in gerbils by $\mathrm{BCCO}(5 \mathrm{~min})$. Animals were killed at $7 \mathrm{~d}$ after ischemia, and brain sections at the level of the dorsal hippocampus were scored for neuronal damage according to Pulsinelli and Brierley (1979). CaEDTA afforded neuroprotection in a substantial number of animals when administered $30 \mathrm{~min}$ before ischemia or at 48 or $60 \mathrm{hr}$ after ischemia but was ineffective when administered at 3 or $6 \mathrm{hr}$ after ischemia. Statistical significance of changes in neuronal counts $(s, t)$ was assessed by means of Student's unpaired $t$ test and of changes in neuronal damage scores $(u)$ by means of ANOVA $\left({ }^{*} p<0.05\right.$; ${ }^{* *} p<0.01$; ${ }^{* * *} p<0.001$ ). Error bars represent SEM. Scale bars: (in $\left.a, i\right) a, c, e, g, i, k, m, 0, q, 500 \mu \mathrm{m}$; (in $\left.b, j\right) b, d, f, h, j, l, n, p$, $r, 50 \mu \mathrm{m}$. so, Stratum oriens; sp, stratum pyramidale; sr, stratum radiatum.
$10 \%$ of control at $5 \mathrm{~d}(n=3 ; p<0.01$ vs control) (Fig. $3 a, c)$. The reduction in GluR2 expression was cell specific in that it was not altered in CA3 pyramidal cells or dentate gyrus granule cells (Fig. 3a). The ischemia-induced alteration in mRNA expression was subunit specific in that GluR1 mRNA was unchanged in all hippocampal subfields at $48 \mathrm{hr}$, corroborated by Pellegrini-Giampietro et al. (1992) and Gorter et al. (1997).

In contrast, in CaEDTA-pretreated animals, ischemia induced a marked, but transient reduction of GluR2 $m$ RNA in the CA1 (reduction to $44.3 \% \pm 4.4 \%$ of control at $48 \mathrm{hr}, n=4, p<0.01 \mathrm{vs}$ control; to $46.1 \pm 8 \%$ of control at $72 \mathrm{hr}, n=4, p<$ 0.01 vs control; and to $88.0 \% \pm 2.8 \%$ of control at $5 \mathrm{~d}, n=4, p<0.01$ vs control) (Fig. 3b,c). Whereas at $48 \mathrm{hr}$ after ischemia, the extent of GluR2 mRNA downregulation was virtually the same in CaEDTAversus saline-injected animals, at $72 \mathrm{hr}$ GluR2 expression was significantly greater in the CaEDTA- versus saline-injected group ( $p<0.01$ vs saline-injected; $p<$ 0.001 vs control). By $5 \mathrm{~d}$ after global ischemia in CaEDTA-treated animals, GluR2 mRNA had recovered to near control levels (to $93.6 \pm 3.4 \%$ of control; $p<0.001$ vs saline-injected; $n=6$ ) (Fig. 3b,c). The transient GluR2 downregulation observed after global ischemia in CaEDTA-treated animals was cell specific in that it was unchanged in CA3 and dentate gyrus (DG) at all times examined. These observations implicate $\mathrm{Zn}^{2+}$ in the persistent downregulation of GluR2 mRNA.

Early CaEDTA attenuates ischemiainduced downregulation of GluR2 protein in CA1

Because GluR2 may also be under translational control, we examined the effects of CaEDTA on the ischemia-induced downregulation of GluR2 protein in CA1. Protein samples from the hippocampal CA1 and dentate gyrus of control and experimental animals were subjected to Western blot analysis. Analysis of band densities indicated that global ischemia reduced GluR2 subunit abundance in CA1, evident at 48 and $72 \mathrm{hr}$ [reduction to $72.8 \pm 7.1 \%$ of control at $48 \mathrm{hr}, n=4$, not significant (n.s.); and to $54.1 \pm 5.5 \%$ of control at 72 hr, $n=3, p<0.01$ ] (Fig. 3d,f). The reduction was subfield selective in that ischemia induced only a modest reduction in GluR2 subunit abundance in dentate gyrus, evident at $72 \mathrm{hr}$ (Fig. 3e,g). CaEDTA significantly attenuated the ischemia-induced downregulation of GluR2 protein in CA1 (ischemic-induced reduction in CaEDTA- 


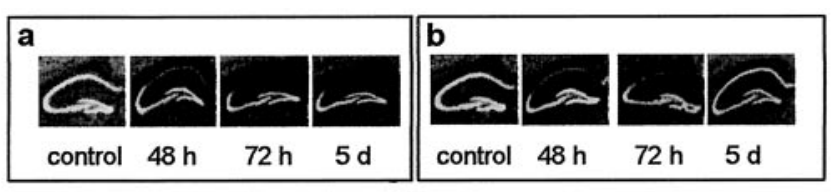

C
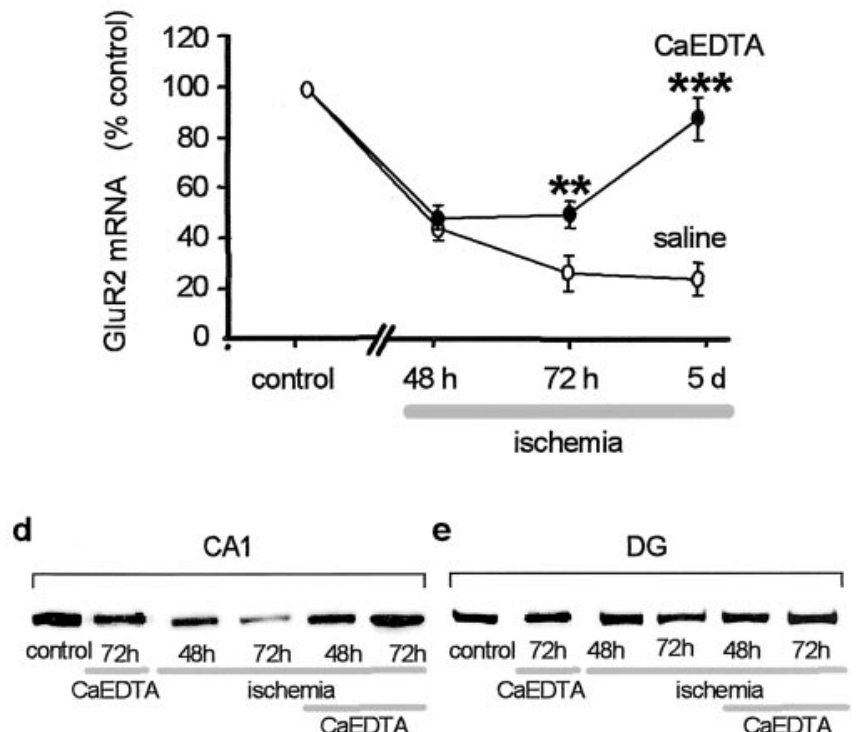

f

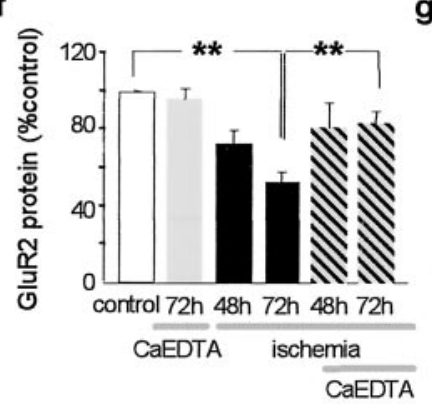

g

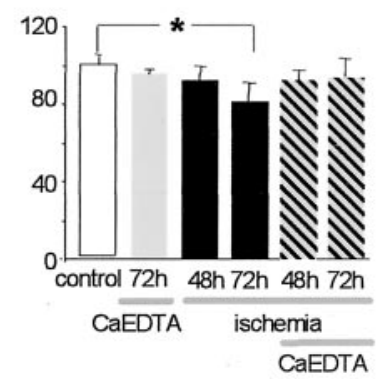

Figure 3. Early CaEDTA attenuates ischemia-induced suppression of GluR2 mRNA and protein in CA1. $a, b$, Representative film autoradiograms of GluR2 mRNA expression detected by in situ hybridization in the hippocampus of control and experimental animals subjected to global ischemia at $48 \mathrm{hr}(n=3), 72 \mathrm{hr}(n=4)$, and $5 \mathrm{~d}(n=3)$ after reperfusion ( $a$ ) or to pretreatment with CaEDTA ( $300 \mathrm{~mm}$, i.c.v.), followed by ischemia at $48 \mathrm{hr}(n=4), 72 \mathrm{hr}(n=4)$, and $5 \mathrm{~d}$ after reperfusion $(n=4)(b)$. c, Quantitative analysis of data such as those in $a, b$. Mean optical densities were normalized to the corresponding control value for a given region. Ischemia caused a loss of GluR2 mRNA in CA1 (but not DG or CA3), evident at $48 \mathrm{hr}$. CaEDTA pretreatment did not alter ischemia-induced downregulation of GluR2 mRNA ( $48 \mathrm{hr}$ ) but accelerated its recovery to control values ( $72 \mathrm{hr}$ and $5 \mathrm{~d}$ ). $d, e$, Representative Western blots probed with a monoclonal antibody against a sequence within the $\mathrm{N}$-terminal domain of the GluR2 subunit. $f$, $g$, Relative GluR2 subunit abundance for protein samples isolated from the CA1 $(f)$ and DG $(g)$ of control $(n=4)$ and experimental animals at $48 \mathrm{hr}$ after CaEDTA injection $(n=4), 48 \mathrm{hr}(n=4)$ and $72 \mathrm{hr}(n=3)$ after ischemia, and at $48 \mathrm{hr}(n=4)$ and $72 \mathrm{hr}(n=4)$ after CaEDTA injection, followed by ischemia. GluR2 abundance was determined from band densities for GluR2 after normalization to the band densities for actin, which served as a loading control. Relative GluR2 subunit abundance was markedly decreased in CA1 (but not DG) at 48 and $72 \mathrm{hr}$ after ischemia. CaEDTA pretreatment attenuated GluR2 downregulation, assessed at $72 \mathrm{hr}$ and $5 \mathrm{~d}$. Bars are means \pm SEM. Statistical significance was assessed by means of Student's unpaired $t$ test $\left({ }^{*} p<0.05 ;{ }^{* *} p<0.01 ;{ }^{* * *} p<0.001\right)$.

treated animals to $81.6 \% \pm 12.9$ of control at $48 \mathrm{hr}, n=4$, n.s. vs control, $p<0.05$ vs saline-injected ischemic animals; and to $84.1 \pm 5.8 \%$ of control at $72 \mathrm{hr}, n=4$, n.s. vs control, $p<0.01$ vs saline-injected ischemic animals) (Fig. $3 d, f$ ) and prevented the slight decrease in GluR2 abundance in dentate gyrus (Fig. 3e,g).
CaEDTA administered $30 \mathrm{~min}$ before sham operation did not detectably alter GluR2 protein abundance in CA1 (Fig. $3 d, f$ ) or DG (Fig. $3 e, g$ ). These findings implicate $\mathrm{Zn}^{2+}$ in the duration and extent of GluR2 protein downregulation.

\section{Early CaEDTA blocks the onset of apoptosis in vulnerable CA1 neurons}

We next examined a possible role for early $\mathrm{Zn}^{2+}$ in the initiation of apoptosis. A major pathway implicated in initiation of the caspase death cascade is the intrinsic (mitochondrial) pathway in which breakdown of the functional integrity of the outer membrane of the mitochondria leads to release of cytochrome $c$ (Shi, 2002; van Loo et al., 2002; Zukin et al., 2004). Once in the cytosol, cytochrome $c$ assembles with Apaf-1, dATP, and procaspase- 9 to form the apoptosome, which activates caspase- 9 , which in turn activates caspase-3. A second mitochondrial activator of caspases (Smac/DIABLO) is coreleased from the mitochondria with cytochrome $c$ (Shi, 2002; van Loo et al., 2002; Zukin et al., 2004). Because the available cytochrome $c$ and Smac/DIABLO antibodies recognize rat (but not gerbil) antigens, we used rats for these experiments and for assay of caspase function, which would be expected to correlate with mitochondrial release of cytochrome $c$. The four-vessel occlusion model of global ischemia in rats is a well established model of global ischemia in which a brief (10 min) ischemic episode affords highly delayed, highly selective death of CA1 pyramidal neurons, which is not manifested until $>48 \mathrm{hr}$. Global ischemia did not significantly alter the abundance of either cytochrome $c$ (Fig. $4 a$ ) or Smac/DIABLO (Fig. $4 c$ ) in the mitochondrial fraction of the CA1 but increased the abundance of cytochrome $c$ (Fig. $4 b$ ) and Smac/DIABLO (Fig. $4 d$ ) in the cytosol, assessed at $12 \mathrm{hr}$ after reperfusion. These data are in confirmation of other studies (Ouyang et al., 1999; Sugawara et al., 1999; Tanaka et al., 2004). CaEDTA reduced the mitochondrial and cytosolic levels of cytochrome $c$ (Fig. 4a,b) and the cytosolic levels of Smac/DIABLO in the CA1 of control animals (Fig. $4 d$ ) and completely blocked the ischemia-elicited rise in cytosolic cytochrome $c$ (Fig. $4 b$ ) and Smac/DIABLO (Fig. $4 d$ ). Together, these findings indicate that CaEDTA strengthens the integrity of the outer mitochondrial membrane in control neurons and prevents the breakdown of the functional integrity of the outer mitochondrial membrane in postischemic neurons. A less likely possibility is that CaEDTA reduces the stability of cytochrome $c$ and Smac/DIABLO in the cytosol.

\section{Early CaEDTA attenuates caspase activity and}

\section{late-stage apoptosis}

Caspase- 3 is a protease and death-promoting protein implicated in the execution step of apoptosis (for review, see Yuan et al., 2003; Tanaka et al., 2004). Global ischemia induces activation of caspase-3, a step critical to ischemia-induced neuronal death (Chen et al., 1998; Tanaka et al., 2004). To examine expression of procaspase- 3 and its proteolytic processing to generate cleaved (activated) caspase-3, we performed Western blot analysis of samples from the CA1 of control and experimental animals. In control animals, abundance of procaspase-3 (32 kDa) (Fig. $5 a$, first lane) and cleaved (activated) caspase-3 (17 kDa) (Fig. $5 b$, first lane) were low in CA1, as assessed by Western analysis. Global ischemia induced a marked increase in procaspase-3 (Fig. $5 a$, second lane) and cleaved caspase- 3 in CA1 (Fig. $5 b$, second lane), evident at $24 \mathrm{hr}$. CaEDTA pretreatment under conditions that afford robust neuroprotection did not detectably alter the ischemia-induced upregulation of procaspases-3 or its proteo- 
a

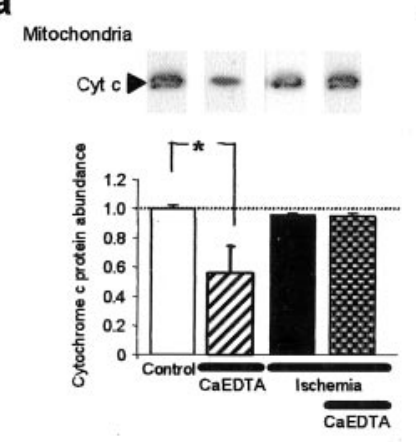

C

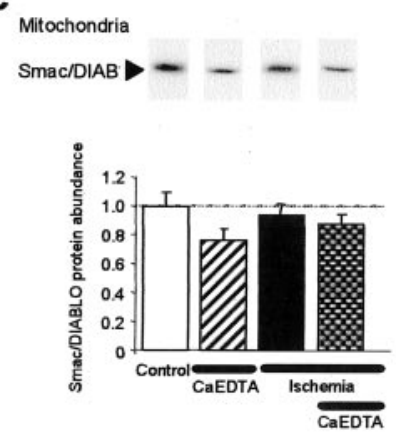

b

Cytoplasm

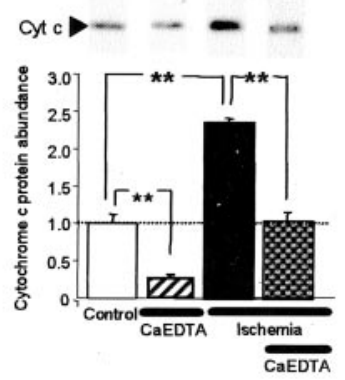

d

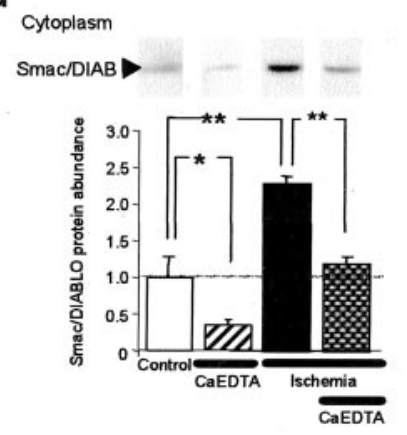

Figure 4. Early CaEDTA blocks the ischemia-induced mitochondrial release of cytochromec (Cyt $c)$ and Smac/DIABLO. Representative Western blots and relative abundance of cytochrome $c(a, b)$ and $\operatorname{Smac} / \operatorname{DIABL} O(c, d)$ in the mitochondrial $(a, c)$ and cytosolic $(b, d)$ fractions of protein samples isolated from control and experimental animals subjected to CaEDTA injection, ischemia, or CaEDTA ( $300 \mathrm{~mm}$, i.c.v.; $30 \mathrm{~min}$ before ischemia), followed by ischemia and killed at 12 $\mathrm{hr}$ after reperfusion. Westerns were probed with anti-cytochrome $\mathrm{c}$ antibody $(a, b)$ or antiSmac/DIABLO antibody $(c, d)$. A single injection of CaEDTA significantly reduced the mitochondrial and cytosolic levels of cytochromec $(a, b)$ and cytosolic levels of Smac/DIABLO $(d)$ in control animals and greatly attenuated the ischemia-induced increase in cytosolic cytochrome $c(b)$ and Smac/DIABL0 (d). Mean band densities for cytochrome cor Smac/DIABL0 in protein samples from the $C A 1$ of experimental animals were normalized to the corresponding values for samples from control animals. Statistical significance was assessed by ANOVA, followed by NewmanKeuls test $\left.{ }^{* *} p<0.01\right)$. Error bars represent SEM.

lytic processing to generate cleaved (activated) caspase-3 (Fig. $5 a, b$, third lane).

The results thus far demonstrate that global ischemia promotes upregulation of the "terminator" protease caspase-3, but do not distinguish between active and inactive protein. To directly measure caspase-3 functional activity, we took advantage of FAM-DEVD-FMK, a fluorescein-tagged analog of the caspase inhibitor zDEVD-FMK. FAM-DEVD-FMK enters cells and binds irreversibly to caspase- 3 and thus provides a fluorescent indicator of the abundance of active caspase-3. In sections of control brain, caspase activity was low (Fig. $5 c, d, i)$. Global ischemia induced a dramatic increase in caspase activity in the hippocampal CAl, evident at $24 \mathrm{hr}$ (Fig. $5 e, f, i)$. The increase in caspase activity was specific in that it was not observed in the resistant CA3 or dentate gyrus. Early injection of CaEDTA caused a marked inhibition of caspase-3 activity, assessed at $24 \mathrm{hr}$ (Fig. $5 g-i)$. These findings are consistent with a model in which early $\mathrm{Zn}^{2+}$ is critical to caspase- 3 activity and onset of apoptosis.

If early CaEDTA indeed arrests caspase activity, it might block apoptotic cascades that occur at late times after ischemia. Global ischemia elicits induction of $\mathrm{p} 75^{\mathrm{NTR}}$, which coincides with the late rise in $\mathrm{Zn}^{2+}$ in selectively vulnerable CA1 neurons (Park et al., 2000). To examine induction of $\mathrm{p} 75^{\mathrm{NTR}}$ and DNA fragmentation in neurons undergoing apoptosis, we performed triple la-

beling of p75 ${ }^{\mathrm{NTR}}$, TUNEL, and Hoechst 33342 (a nuclear stain) on sections of hippocampus from experimental and control animals $72 \mathrm{hr}$ after global ischemia (Fig. $5 j-u$ ). $p 75^{\mathrm{NTR}}$ is a proapoptotic neurotrophin receptor that can trigger apoptotic cell death via a death-receptor-dependent pathway (Roux and Barker, 2002) and provides a marker for neurons undergoing apoptosis in animals subjected to seizures (Roux et al., 1999) or global ischemia (Park et al., 2000; Jover et al., 2002; Tanaka et al., 2004). We used a TUNEL technique in which a terminal deoxynucleotidyl transferase transfers fluorescein "tags" to nicked ends present in fragmented DNA. In sections from control brain, p $75^{\text {NTR }}$ immunoreactivity and TUNEL labeling were undetectable in the pyramidal cell layers of the CA1 (Fig. $5 j-l$ ) and in other subfields of the hippocampus (data not shown). Global ischemia induced marked $\mathrm{p} 75^{\mathrm{NTR}}$ immunoreactivity and TUNEL positivity in CA1 pyramidal neurons, evident at $72 \mathrm{hr}(n=3$ per treatment group) (Fig. $5 m-r$ ), in confirmation of our previous results (Jover et al., 2002). These findings indicate that $\mathrm{p} 75^{\mathrm{NTR}}$ expression occurs in postischemic CA1 neurons undergoing apoptosis. Early injection of CaEDTA greatly attenuated $\mathrm{p} 75^{\mathrm{NTR}}$ expression [in confirmation of Park et al. (2000)] and blocked DNA fragmentation in CA1 (Fig. $5 s-u$ ). These findings demonstrate that early CaEDTA intervenes downstream of proteolytic processing and activation of caspase- 3 and upstream of $\mathrm{p} 75^{\text {NTR }}$ expression and DNA fragmentation to protect CA1 neurons and implicate $\mathrm{Zn}^{2+}$ in the late stages of apoptotic cell death.

\section{Late CaEDTA prevents the delayed rise in $\mathrm{Zn}^{2+}$ and late-stage apoptosis}

Our findings indicate a substantial delay $(48-72 \mathrm{hr}$ ) between ischemic insult and $\mathrm{Zn}^{2+}$ accumulation in selectively vulnerable neurons. These observations raise the possibility that late injections of CaEDTA should prevent the late $\mathrm{Zn}^{2+}$ rise in CA1 neurons. To examine this hypothesis, we subjected animals to global ischemia, followed by administration of CaEDTA at $60 \mathrm{hr}$, and assessed intracellular $\mathrm{Zn}^{2+}$ concentration by TSQ labeling of brain sections at the level of the dorsal hippocampus. As in Figure 1 , global ischemia induced a pronounced rise in $\mathrm{Zn}^{2+}$ fluorescence in cell bodies of CA1 pyramidal neurons, evident at 72 (Figs. $6 c, 1 i, j$ ) but not $48 \mathrm{hr}$ (Figs. $6 b, 1 g, h$ ). CaEDTA injected at 60 $\mathrm{hr}$ after ischemia, a time when downregulation of GluR2 protein and expression of GluR2-lacking AMPARs are pronounced, substantially attenuated the late rise in intracellular $\mathrm{Zn}^{2+}$ in CA1 neurons (similar results were observed in eight of eight animals subjected to ischemia, followed by CaEDTA at $60 \mathrm{hr}$ ) (Fig. $6 d-f$ ). These findings do not, however, distinguish between chelation of extracellular $\mathrm{Zn}^{2+}$ before its entry into postsynaptic neurons versus chelation of intracellular $\mathrm{Zn}^{2+}$ as it leeches out of degenerating CA1 neurons.

Whereas release of cytochrome $c$ and caspase- 3 activation occur in the first $3 \mathrm{hr}$ after insult, induction of $\mathrm{p} 75^{\mathrm{NTR}}$ and onset of DNA fragmentation do not occur until $\sim 72 \mathrm{hr}$ after global ischemia (Zukin et al., 2004). We therefore examined the effects of late CaEDTA on these markers of end-stage apoptosis. As in Figure 5, global ischemia induced a marked increase in $\mathrm{p} 75^{\mathrm{NTR}}$ and TUNEL staining in CA1 neurons at $72 \mathrm{hr}$ after ischemia $(n=3$ per treatment group) (Figs. $6 k, l, 5 m-r)$. Late injection of CaEDTA (60 hr after ischemia) greatly attenuated induction of p $75^{\text {NTR }}$ expression and DNA fragmentation in CA1 neurons (Fig. $6 m-o$, typical of five of five animals). Thus, late injection of CaEDTA blocks end-stage apoptosis and rescues CA1 neurons from ischemic cell death. 


\section{Discussion}

Considerable evidence suggests that $\mathrm{Zn}^{2+}$ at high intracellular concentrations is a critical mediator of the neuronal death associated with global ischemia, seizures, traumatic brain injury, and other brain disorders (Choi and Koh, 1998; Weiss et al., 2000; Dineley et al., 2003; Zukin et al., 2004). Global ischemia elicits a delayed rise in $\mathrm{Zn}^{2+}$ in the cell bodies of selectively vulnerable CA1 neurons before the onset of cell death (Koh et al., 1996; Park et al., 2000). CaEDTA pretreatment prevents late $\mathrm{Zn}^{2+}$ accumulation and protects CA1 neurons (Koh et al., 1996; Park et al., 2000). The substantial delay between neuronal insult and rise in toxic $\mathrm{Zn}^{2+}$ suggests the opportunity for intervention at late times after ischemia. Here we show the striking finding that CaEDTA administered as late as $60 \mathrm{hr}$ after global ischemia affords robust protection of CA1 neurons in $\sim 50 \%$ of animals. In contrast, the selective caspase- 3 inhibitor $z$-DEVD-FMK affords robust protection of neurons against ischemic death when administered before or $2 \mathrm{hr}$ after ischemia (Chen et al., 1998), but not when administered at 6-72 hr after ischemia (our unpublished observations). Thus, diverse protective strategies exhibit different windows of therapeutic intervention. The finding of neuroprotection by late CaEDTA administration has powerful implications for intervention in ischemia-induced neuronal death and supports $\mathrm{Zn}^{2+}$ as an important target for future therapeutic approaches.

We also show that $\mathrm{Zn}^{2+}$ acts via temporally distinct mechanisms to promote neuronal death. CaEDTA pretreatment attenuates ischemia-induced GluR2 mRNA and protein downregulation (and, by inference, expression of GluR2-lacking $\mathrm{Zn}^{2+}$-permeable AMPARs), the delayed rise in $\mathrm{Zn}^{2+}$, and neuronal death. These findings indicate that $\mathrm{Zn}^{2+}$ acts at step(s) upstream from GluR2 gene expression and implicate early $\mathrm{Zn}^{2+}$ in transcriptional regulation and/or mRNA stability. In CaEDTA-treated animals, ischemia induces transient GluR2 downregulation, indicating that REST and GluR2 expression return to control levels in protected cells. Early CaEDTA also blocks the release of cytochrome $c$ and Smac/DIABLO from the mitochondria, an event that occurs within the first $1-2 \mathrm{hr}$ after insult. These findings are consistent with observations that exposure of isolated mitochondria to $\mathrm{Zn}^{2+}$ in vitro induces release of cytochrome $c$, apoptosis-inducing factor, and Smac/DIABLO (Jiang et al., 2001). An in- a
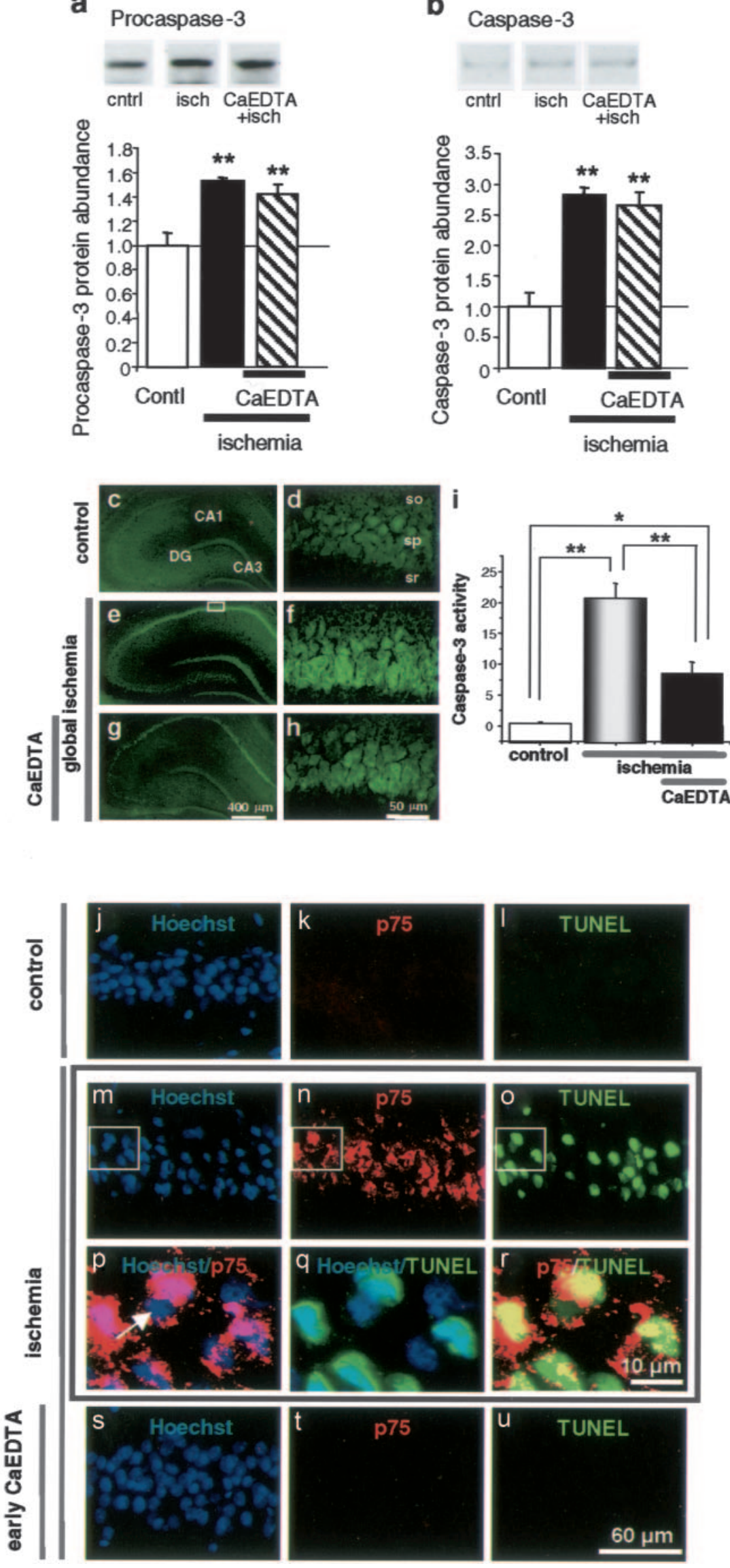

b

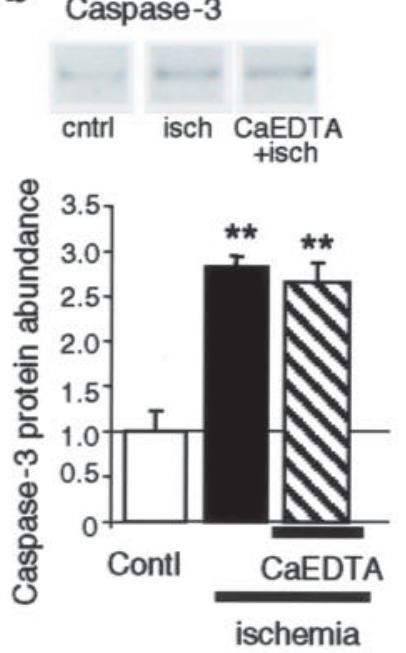



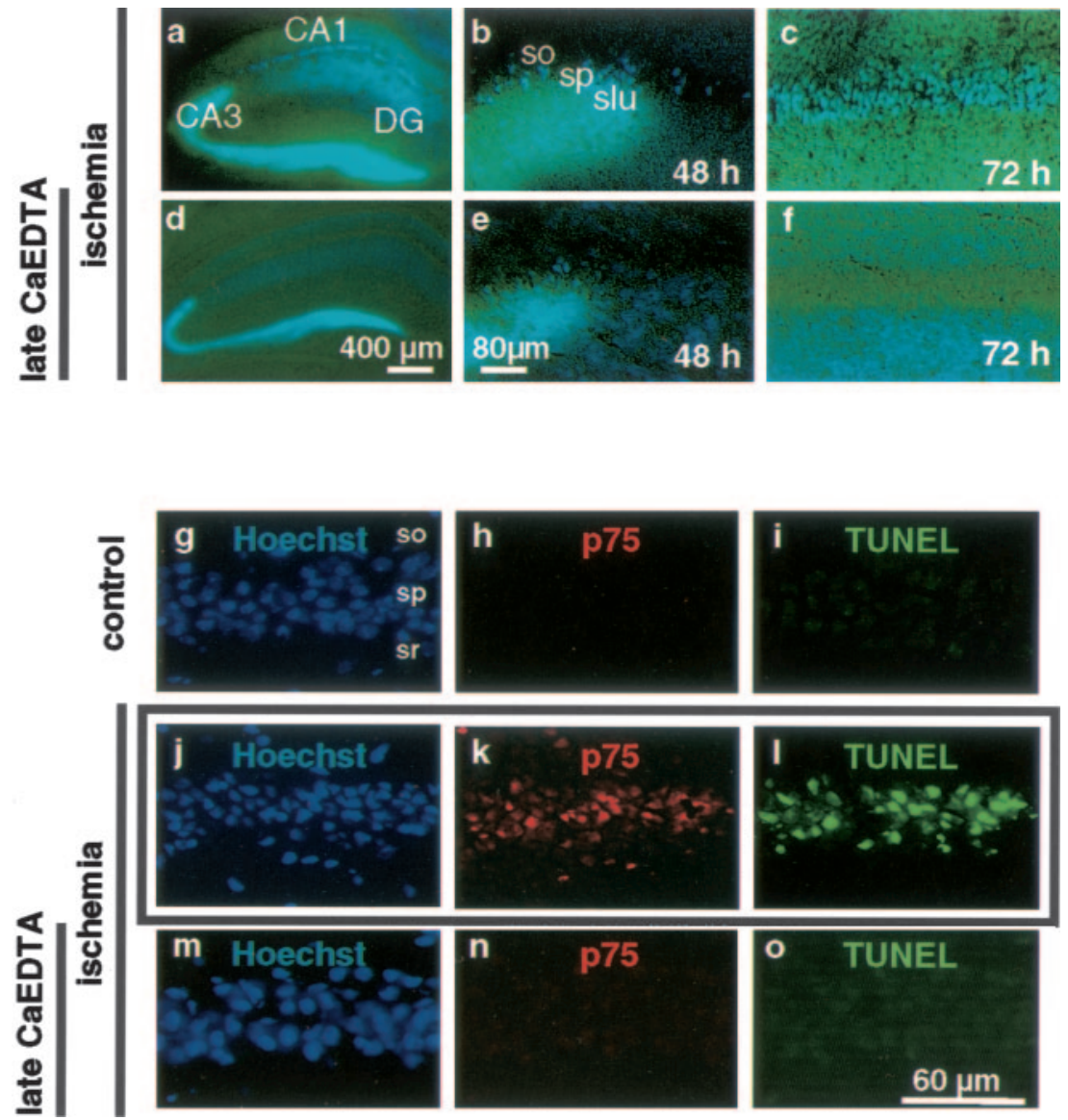

Figure 6. Late CaEDTA blocks the ischemia-induced rise in $\mathrm{Zn}^{2+}$ and late-stage apoptosis in CA1 neurons. $\mathrm{Zn}^{2+}$ fluorescence in TSQ-stained coronal brain sections from experimental animals subjected to global ischemia $(a-c)$ or to global ischemia, followed by CaEDTA ( $300 \mathrm{~mm}$, i.c.v. at $60 \mathrm{hr}$ ) and killed at $72 \mathrm{hr}$ after reperfusion $(d-f)$. Global ischemia induced a pronounced increase in $\mathrm{Zn}^{2+}$ fluorescence in the cell bodies of scattered hilar neurons ( $a$ ) and CA3 pyramidal neurons (b). At $72 \mathrm{hr}, \mathrm{Zn}^{2+}$ fluorescence was pronounced in cell bodies of CA1 pyramidal neurons ( $c$. Late injection of CaEDTA prevented the rise in $\mathrm{Zn}^{2+}$ fluorescence in CA1 neurons. $g-0$, Representative brain sections at the level of the dorsal hippocampus labeled with the nuclear stain Hoechst $33342(g, j, m)$, an anti-p75 ${ }^{\text {NTR }}$ antibody $(h, k, n)$, and TUNEL $(i, l, 0)$ from control $(g-i)$ and experimental gerbils subjected to global ischemia ( $j-l$ ) or to global ischemia followed by CaEDTA ( $300 \mathrm{~mm}$, i.c.v. at $60 \mathrm{hr}$ ) and killed at $72 \mathrm{hr}$ after reperfusion $(m-0) . p 75^{\text {NTR }}$ immunolabeling visualized in red (Texas Red), TUNEL reaction in green (fluorescein), and Hoechststained nuclei in blue. so, Stratum oriens; sp, stratum pyramidale; sr, stratum radiatum. Coincidence of $p 75^{\text {NTR }}$ immunolabeling and TUNEL positivity was observed in neurons throughout the CA1 pyramidal cell layer; CaEDTA injection at $60 \mathrm{hr}$ after reperfusion markedly reduced p $75^{\mathrm{NTR}}$ expression and TUNEL. Scale bars: $a, d, 400 \mu \mathrm{m} ; b, c, e, f, 80 \mu \mathrm{m} ; g-0,60 \mu \mathrm{m}$.

Figure 5. Early CaEDTA acts downstream of caspase-3 cleavage to block caspase-3 activity, p75 NTR induction, and TUNEL. Representative Western blots and relative abundance of procaspase-3 $(a)$ and caspase- $3(b)$ in protein samples isolated from control (Contl) and experimental animals subjected to ischemia or CaEDTA (300 mm, i.c.v.; 30 min before ischemia), followed by ischemia and killed at $24 \mathrm{hr}$ after reperfusion. Westerns were probed with an anti-caspase- 3 antibody. Global ischemia induced an upregulation of procaspase-3 $(a$ ) and promoted its proteolytic processing to generate cleaved (activated) caspase-3 $(b)$. CaEDTA did not significantly alter the ischemia-induced upregulation of procaspase- $3(a)$ or the appearance of caspase- $3(b)$. Mean band densities for procaspase- 3 and cleaved (activated) caspase-3 in protein samples from the CA1 of experimental animals were normalized to the corresponding values for samples from control animals. Representative brain sections at the level of the dorsal hippocampus from animals subjected to sham operation (control; $c, d$ ), global ischemia (e,f), or CaEDTA ( $300 \mathrm{~mm}$, i.c.v.; 30 min before ischemia), followed by ischemia and killed at $24 \mathrm{hr}(g, h)$, labeled with FAM-DEVD-FMK, a fluorescein-tagged analog of zDEVD-FMK, a potent inhibitor of activated caspases. $c, d$, Caspase-3 activity was low in control brain. $e, f$, Global ischemia induced caspase-3 activity in the CA1 pyramidal cell layer, evident at $24 \mathrm{hr}(g, h)$. $i$, Summary of data for animals subjected to sham operation, ischemia, or CaEDTA, followed by ischemia. Scale bars, $400 \mu \mathrm{m}$ (low magnification); $50 \mu \mathrm{m}$ (high magnification). Error bars represent SEM. $j-u$, Triple labeling of representative brain sections with the nuclear stain Hoechst $33342(j, m, p, s)$, an anti-p75 ${ }^{\mathrm{NTR}}$ antibody $(k, n, q, t)$, and TUNEL $(l, 0, r, u)$ in the CA1 pyramidal layer of control $(j, I)$ and experimental gerbils subjected to global ischemia $(m-r)$ or to CaEDTA ( $300 \mathrm{~mm}$, i.c.v.; 30 min before ischemia), followed by ischemia and killed at $72 \mathrm{hr}(s-u)$. $p$ is the superimposition of $m$ and $n$. $q$ is a superimposition of $m$ and 0 . $r$ is a superimposition of $n$ and o. Indicated boxes are enlarged in $p-r$. p $75^{\mathrm{NTR}}$ immunolabeling visualized in red (Texas Red), TUNEL in green (fluorescein), and Hoechst in blue. so, Stratum oriens; sp, stratum pyramidale; sr, stratum radiatum. Global ischemia induced $755^{\mathrm{NTR}}$ expression and TUNEL positivity in CA1 pyramidal neurons; CaEDTA pretreatment reduced $p 75^{\text {NTR }}$ immunolabeling and TUNEL. Scale bars: (in $r$ ) $p-r, 10 \mu \mathrm{m}$; (in $u$ ) $j-0$ and $s-u, 60 \mu \mathrm{m}$. Statistical significance in $a, b, i$ was assessed by ANOVA, followed by Newman-Keuls test $\left({ }^{*} p<0.05\right.$; $\left.{ }^{* *} p<0.01\right)$. ferred conclusion is that CaEDTA preserves the functional integrity of the mitochondrial outer membrane. Late CaEDTA, administered at a time when GluR2 is downregulated and newly synthesized $\mathrm{Zn}^{2+}$-permeable AMPARs are expressed (Pellegrini-Giampietro et al., 1997), directly chelates $\mathrm{Zn}^{2+}$ as it rises and prevents $\mathrm{p} 75^{\mathrm{NTR}}$ induction and DNA fragmentation, thereby enabling neurons to survive. These findings extend findings by others that CaEDTA administration before ischemia prevents $\mathrm{p} 75^{\mathrm{NTR}}$ and NADE expression (Park et al., 2000) and implicate $\mathrm{Zn}^{2+}$ in the end-stages of apoptosis in ischemia-induced neuronal death.

\section{The timing issue}

Global ischemia in vivo elicits a delayed rise in neurotoxic $\mathrm{Zn}^{2+}$ and onset of neuronal death in CA1 neurons $48-72 \mathrm{hr}$ after insult. In contrast, the functional "halflife" of CaEDTA in vivo is $\sim 90$ min (Frederickson et al., 2002); thus, the duration of direct action of early CaEDTA is extinguished 48-72 hr before the rise in $\mathrm{Zn}^{2+}$ and death of CA1 neurons. How then does early CaEDTA prevent the late rise in neurotoxic $\mathrm{Zn}^{2+}$ ? Findings in the present study implicate early $\mathrm{Zn}^{2+}$ at nearphysiological concentrations in transcriptional changes and/or mRNA stability, and in the initiation of apoptotic death cascades, and raise the possibility of a causal relationship between these early events and the late rise in toxic $\mathrm{Zn}^{2+}$. The observation that CaEDTA reduces the duration and extent of GluR2 protein downregulation is consistent with an additional role for $\mathrm{Zn}^{2+}$ in translational regulation and/or protein stability. By shortening the duration of GluR2 mRNA downregulation and reducing the duration and extent of GluR2 protein downregulation, CaEDTA would impede assembly and insertion of functional GluR2-lacking AMPARs observed at synaptic and extrasynaptic sites of postischemic CA1 neurons at late times after insult (Gorter et al., 1997). Because the delayed rise in $\mathrm{Zn}^{2+}$ may occur, at least in part, via GluR2-lacking AMPARs (Yin et al., 2002), CaEDTA would prevent $\mathrm{Zn}^{2+}$ entry into CA1 neurons. Although not addressed by the present study, an attractive hypothesis is that early CaEDTA depletes extracellular $\mathrm{Zn}^{2+}$ [and intracellular $\mathrm{Zn}^{2+}$, which leeches out of CA1 neurons as extracellular $\mathrm{Zn}^{2+}$ is depleted ( $\mathrm{Li}$ et al., 2001)] and thereby ultimately inhibits activity of REST, a nine zinc finger transcription factor that represses neuralspecific targets, including GluR2. By blocking cytochrome $c$ release, a key step 
in the intrinsic or mitochondrial pathway of caspase activation, CaEDTA could halt the self-amplifying caspase death cascade and thereby block DNA fragmentation and apoptotic cell death.

\section{The source of the late rise in neurotoxic $\mathrm{Zn}^{2+}$}

An important unresolved issue is the source of the late rise in $\mathrm{Zn}^{2+}$ in CA1 neurons. Early studies proposed that neurotoxic $\mathrm{Zn}^{2+}$ translocated from presynaptic to postsynaptic cells in response to high neuronal activity or insult (Koh et al., 1996). This notion was supported by observations that CaEDTA, a membrane-impermeant chelator of extracellular $\mathrm{Zn}^{2+}$ (Koh et al., 1996), and 1-naphthylacetylspermine, a selective channel blocker of GluR2-lacking AMPARs, block the ischemia-induced rise in intracellular $\mathrm{Zn}^{2+}$ and cell death in in vitro (Yin et al., 2002) and in vivo models of ischemia (our unpublished observations). Moreover, whereas overexpression of $\mathrm{Ca}^{2+} / \mathrm{Zn}^{2+}$ impermeable GluR2(R) channels, using shutoff-deficient Semliki Forest Virus-based vectors, blocks $\mathrm{Ca}^{2+}$ and/or $\mathrm{Zn}^{2+}$ influx and affords protection of CA1 neurons, overexpression of $\mathrm{Ca}^{2+}$ / $\mathrm{Zn}^{2+}$-permeable GluR2 (Q) channels induces neuronal death in otherwise resistant granule neurons of the dentate gyrus (Liu et al., 2004). On the other hand, $\mathrm{Zn}^{2+}$ accumulates in degenerating $\mathrm{CA} 1 / \mathrm{CA} 3$ pyramidal neurons of $\mathrm{ZnT}-3$-null mice in response to kainate-elicited seizures despite the virtual absence of vesicular $\mathrm{Zn}^{2+}$ (Lee et al., 2000). This finding suggests that the $\mathrm{Zn}^{2+}$ accumulation in postischemic neurons of wild-type animals originates from sources other than synaptic vesicles as, for example, intracellular stores comprised primarily of $\mathrm{Zn}^{2+}$ metalloenzymes such as metallothionein and zinc finger-containing transcription factors. Consistent with this, exposure of neurons in culture to oxidative stress promotes the release of $\mathrm{Zn}^{2+}$ from intracellular stores, an event critical to initiation of neuronal apoptosis (Aizenman et al., 2000). Indeed, a more recent evaluation of CaEDTA reveals an ability to chelate both extracellular and intracellular $\mathrm{Zn}^{2+}$, which exhibits significant mobility across neuronal membranes (Frederickson et al., 2002).

\section{Mechanisms by which late $\mathrm{Zn}^{2+}$ promotes neuronal death}

The molecular mechanisms by which $\mathrm{Zn}^{2+}$ mediates neuronal death have begun to be unraveled in the past few years, primarily from studies of isolated mitochondria and neurons in culture. Whereas relatively low concentrations of $\mathrm{Zn}^{2+}(\sim 20 \mu \mathrm{M})$ elicit neuronal death with the hallmarks of apoptosis, higher concentrations of $\mathrm{Zn}^{2+}(50-100 \mu \mathrm{M})$ elicit neuronal death that is characteristically necrotic (Kim et al., 1999). Mechanisms by which $\mathrm{Zn}^{2+}$ elicits neuronal death include production of free radicals, loss of mitochondrial membrane potential, formation of the mitochondrial transition pore, dysregulation of the electron transport chain, disruption of glycolysis, production of reactive oxygen species, and reduction in cellular ATP (Choi and Koh, 1998; Weiss et al., 2000; Dineley et al., 2003; Zukin et al., 2004). The present study extends our understanding of how $\mathrm{Zn}^{2+}$ kills neurons in an in vivo model of global ischemia: early $\mathrm{Zn}^{2+}$ at nearphysiological concentrations is necessary for the breakdown of the functional integrity of the mitochondrial outer membrane and maintained caspase activity and is critical to transcriptional changes that promote neuronal death; late $\mathrm{Zn}^{2+}$ at high intracellular concentrations promotes induction of the $\mathrm{p} 75^{\mathrm{NTR}}$ death cascade, DNA fragmentation, and end-stage apoptosis.

\section{Zinc chelation as a potential clinical strategy}

Perhaps the most compelling finding of this paper is the neuroprotection provided by late CaEDTA. Late CaEDTA attenuates
$\mathrm{Zn}^{2+}$ accumulation, $\mathrm{p} 75^{\mathrm{NTR}}$ upregulation, and TUNEL activity in virtually all animals, yet when administered at either 48 or 60 hr, protects CA1 neurons in only approximately one-half of the animals. To explain these data, we hypothesize that $\mathrm{Zn}^{2+}$ initiates the final stages of death at different times in different animals. Because the action of CaEDTA lasts $<90 \mathrm{~min}$, CaEDTA at $48 \mathrm{hr}$ might protect neurons in the subset of animals that are poised and ready to undergo irreversible, $\mathrm{Zn}^{2+}$-mediated damage, but not in animals in which $\mathrm{Zn}^{2+}$ damage is relatively more delayed. CaEDTA at $60 \mathrm{hr}$ would afford protection in animals in which damage is relatively delayed but could not rescue neurons in which irreversible damage had already occurred. Given that $\mathrm{Zn}^{2+}$ is required for normal function and that excessive chelation is likely to be deleterious, more complex dosage regimens clearly should be investigated. Furthermore, the possibility of buffering $\mathrm{Zn}^{2+}$ at different levels should be evaluated. The observation in the present study that late $\mathrm{Zn}^{2+}$ chelation protects neurons in a substantial fraction of animals provides a powerful impetus for these studies.

\section{References}

Aizenman E, Stout AK, Hartnett KA, Dineley KE, McLaughlin B, Reynolds IJ (2000) Induction of neuronal apoptosis by thiol oxidation: putative role of intracellular zinc release. J Neurochem 75:1878-1888.

Bers DM, Patton CW, Nuccitelli R (1994) A practical guide to the preparation of Ca2+ buffers. Methods Cell Biol 40:3-29.

Brene S, Messer C, Okado H, Hartley M, Heinemann SF, Nestler EJ (2000) Regulation of GluR2 promoter activity by neurotrophic factors via a neuron-restrictive silencer element. Eur J Neurosci 12:1525-1533.

Bresink I, Ebert B, Parsons CG, Mutschler E (1996) Zinc changes AMPA receptor properties: results of binding studies and patch clamp recordings. Neuropharmacology 35:503-509.

Calderone A, Jover T, Noh K-M, Tanaka H, Yokota H, Lin Y, Grooms S, Regis R, Bennett MVL, Zukin RS (2003) Ischemic insults derepress the gene silencer REST in neurons destined to die. J Neurosci 23:2112-2121.

Chen J, Nagayama T, Jin K, Stetler RA, Zhu RL, Graham SH, Simon RP (1998) Induction of caspase-3-like protease may mediate delayed neuronal death in the hippocampus after transient cerebral ischemia. J Neurosci 18:4914-4928.

Choi DW, Koh JY (1998) Zinc and brain injury. Annu Rev Neurosci 21:347-375.

Christine CW, Choi DW (1990) Effect of zinc on NMDA receptor-mediated channel currents in cortical neurons. J Neurosci 10:108-116.

Colbourne F, Grooms SY, Zukin RS, Buchan AM, Bennett MV (2003) Hypothermia rescues hippocampal CA1 neurons and attenuates downregulation of the AMPA receptor GluR2 subunit after forebrain ischemia. Proc Natl Acad Sci USA 100:2906-2910.

Dawson RMC, Elliot DC, Elliot WH, Jones KM (1984) Data for Biochemical Research. New York: Oxford Science.

Dineley KE, Votyakova TV, Reynolds IJ (2003) Zinc inhibition of cellular energy production: implications for mitochondria and neurodegeneration. J Neurochem 85:563-570.

Frederickson CJ, Kasarskis EJ, Ringo D, Frederickson RE (1987) A quinoline fluorescence method for visualizing and assaying the histochemically reactive zinc (bouton zinc) in the brain. J Neurosci Methods 20:91-103.

Frederickson CJ, Suh SW, Koh JY, Cha YK, Thompson RB, LaBuda CJ, Balaji RV, Cuajungco MP (2002) Depletion of intracellular zinc from neurons by use of an extracellular chelator in vivo and in vitro. J Histochem Cytochem 50:1659-1662.

Golub MS, Keen CL, Gershwin ME, Hendrickx AG (1995) Developmental zinc deficiency and behavior. J Nutr 125:2263S-2271S.

Gorter JA, Petrozzino JJ, Aronica EM, Rosenbaum DM, Opitz T, Bennett MVL, Connor JA, Zukin RS (1997) Global ischemia induces downregulation of Glur2 mRNA and increases AMPA receptor-mediated $\mathrm{Ca}^{2+}$ influx in hippocampal CA1 neurons of gerbil. J Neurosci 17:6179-6188.

Henkin RI, Patten BM, Re PK, Bronzert DA (1975) A syndrome of acute zinc loss. Cerebellar dysfunction, mental changes, anorexia, and taste and smell dysfunction. Arch Neurol 32:745-751.

Huang Y, Myers SJ, Dingledine R (1999) Transcriptional repression by 
REST: recruitment of Sin3A and histone deacetylase to neuronal genes. Nat Neurosci 2:867-872.

Huang Y, Doherty JJ, Dingledine R (2002) Altered histone acetylation at glutamate receptor 2 and brain-derived neurotrophic factor genes is an early event triggered by status epilepticus. J Neurosci 22:8422-8428.

Jiang D, Sullivan PG, Sensi SL, Steward O, Weiss JH (2001) Zn(2+) induces permeability transition pore opening and release of pro-apoptotic peptides from neuronal mitochondria. J Biol Chem 276:47524-47529.

Jover T, Tanaka H, Calderone A, Oguro K, Bennett MV, Etgen AM, Zukin RS (2002) Estrogen protects against global ischemia-induced neuronal death and prevents activation of apoptotic signaling cascades in the hippocampal CA1. J Neurosci 22:2115-2124.

Kay AR (2003) Evidence for chelatable zinc in the extracellular space of the hippocampus, but little evidence for synaptic release of $\mathrm{Zn}$. J Neurosci 23:6847-6855.

Kim YH, Kim EY, Gwag BJ, Sohn S, Koh JY (1999) Zinc-induced cortical neuronal death with features of apoptosis and necrosis: mediation by free radicals. Neuroscience 89:175-182.

Koh JY (2001) Zinc and disease of the brain. Mol Neurobiol 24:99-106.

Koh JY, Suh SW, Gwag BJ, He YY, Hsu CY, Choi DW (1996) The role of zinc in selective neuronal death after transient global cerebral ischemia. Science 272:1013-1016.

Lee JY, Cole TB, Palmiter RD, Koh JY (2000) Accumulation of zinc in degenerating hippocampal neurons of ZnT3-null mice after seizures: evidence against synaptic vesicle origin. J Neurosci 20:RC79(1-5).

Lerma J, Morales M, Ibarz JM, Somohano F (1994) Rectification properties and $\mathrm{Ca} 2+$ permeability of glutamate receptor channels in hippocampal cells. Eur J Neurosci 6:1080-1088.

Li Y, Hough CJ, Suh SW, Sarvey JM, Frederickson CJ (2001) Rapid translocation of $\mathrm{Zn}(2+)$ from presynaptic terminals into postsynaptic hippocampal neurons after physiological stimulation. J Neurophysiol 86:2597-2604.

Liu S, Lau L, Wei J, Zhu D, Zou S, Sun HS, Fu Y, Liu F, Lu Y (2004) Expression of $\mathrm{Ca}(2+)$-permeable AMPA receptor channels primes cell death in transient forebrain ischemia. Neuron 43:43-55.

Lu YM, Taverna FA, Tu R, Ackerley CA, Wang YT, Roder J (2000) Endogenous $\mathrm{Zn}(2+)$ is required for the induction of long-term potentiation at rat hippocampal mossy fiber-CA3 synapses. Synapse 38:187-197.

Oguro K, Oguro N, Kojima T, Grooms SY, Calderone A, Zheng X, Bennett MV, Zukin RS (1999) Knockdown of AMPA receptor GluR2 expression causes delayed neurodegeneration and increases damage by sublethal ischemia in hippocampal CA1 and CA3 neurons. J Neurosci 19:9218-9227.

Opitz T, Grooms SY, Bennett MV, Zukin RS (2000) Remodeling of alphaamino-3-hydroxy-5-methyl-4-isoxazole-propionic acid receptor subunit composition in hippocampal neurons after global ischemia. Proc Natl Acad Sci USA 97:13360-13365.

Ouyang YB, Tan Y, Comb M, Liu CL, Martone ME, Siesjo BK, Hu BR (1999) Survival- and death-promoting events after transient cerebral ischemia: phosphorylation of Akt, release of cytochrome $\mathrm{C}$ and activation of caspase-like proteases. J Cereb Blood Flow Metab 19:1126-1135.

Palmiter RD, Cole TB, Findley SD (1996) ZnT-2, a mammalian protein that confers resistance to zinc by facilitating vesicular sequestration. EMBO J 15:1784-1791.

Park JA, Lee JY, Sato TA, Koh JY (2000) Co-induction of p75NTR and p75NTR-associated death executor in neurons after zinc exposure in cortical culture or transient ischemia in the rat. J Neurosci 20:9096-9103.

Pellegrini-Giampietro DE, Zukin RS, Bennett MV, Cho S, Pulsinelli WA (1992) Switch in glutamate receptor subunit gene expression in CA1 subfield of hippocampus following global ischemia in rats. Proc Natl Acad Sci USA 89:10499-10503.

Pellegrini-Giampietro DE, Gorter JA, Bennett MV, Zukin RS (1997) The GluR2 (GluR-B) hypothesis: $\mathrm{Ca}(2+)$-permeable AMPA receptors in neurological disorders. Trends Neurosci 20:464-470.

Peters S, Koh J, Choi DW (1987) Zinc selectively blocks the action of $\mathrm{N}$-methyl-D-aspartate on cortical neurons. Science 236:589-593.

Pozarowski P, Huang X, Halicka DH, Lee B, Johnson G, Darzynkiewicz Z (2003) Interactions of fluorochrome-labeled caspase inhibitors with apoptotic cells: a caution in data interpretation. Cytometry 55A:50-60.

Pulsinelli WA, Brierley JB (1979) A new model of bilateral hemispheric ischemia in the unanesthetized rat. Stroke 10:267-272.

Rassendren FA, Lory P, Pin JP, Nargeot J (1990) Zinc has opposite effects on NMDA and non-NMDA receptors expressed in Xenopus oocytes. Neuron 4:733-740.

Roux PP, Barker PA (2002) Neurotrophin signaling through the p75 neurotrophin receptor. Prog Neurobiol 67:203-233.

Roux PP, Colicos MA, Barker PA, Kennedy TE (1999) p75 neurotrophin receptor expression is induced in apoptotic neurons after seizure. J Neurosci 19:6887-6896.

Sensi SL, Yin HZ, Carriedo SG, Rao SS, Weiss JH (1999) Preferential Zn2+ influx through $\mathrm{Ca} 2+$-permeable AMPA/kainate channels triggers prolonged mitochondrial superoxide production. Proc Natl Acad Sci USA 96:2414-2419.

Shi Y (2002) Mechanisms of caspase activation and inhibition during apoptosis. Mol Cell 9:459-470.

Sugawara T, Fujimura M, Morita-Fujimura Y, Kawase M, Chan PH (1999) Mitochondrial release of cytochrome c corresponds to the selective vulnerability of hippocampal CA1 neurons in rats after transient global cerebral ischemia. J Neurosci 19:RC39(1-6).

Tanaka H, Yokota H, Jover T, Cappuccio I, Calderone A, Simionescu M, Bennett MV, Zukin RS (2004) Ischemic preconditioning: neuronal survival in the face of caspase-3 activation. J Neurosci 24:2750-2759.

Toomim CS, Millington WR (1998) Regional and laminar specificity of kainate-stimulated cobalt uptake in the rat hippocampal formation. J Comp Neurol 402:141-154.

van Loo G, Saelens X, van Gurp M, MacFarlane M, Martin SJ, Vandenabeele P (2002) The role of mitochondrial factors in apoptosis: a Russian roulette with more than one bullet. Cell Death Differ 9:1031-1042.

Vogt K, Mellor J, Tong G, Nicoll R (2000) The actions of synaptically released zinc at hippocampal mossy fiber synapses. Neuron 26:187-196.

Weiss JH, Sensi SL, Koh JY (2000) Zn(2+): a novel ionic mediator of neural injury in brain disease. Trends Pharmacol Sci 21:395-401.

Westbrook GL, Mayer ML (1987) Micromolar concentrations of Zn2+ antagonize NMDA and GABA responses of hippocampal neurons. Nature 328:640-643.

Yin HZ, Sensi SL, Carriedo SG, Weiss JH (1999) Dendritic localization of $\mathrm{Ca}(2+)$-permeable AMPA/kainate channels in hippocampal pyramidal neurons. J Comp Neurol 409:250-260.

Yin HZ, Sensi SL, Ogoshi F, Weiss JH (2002) Blockade of $\mathrm{Ca}^{2+}$-permeable AMPA/kainate channels decreases oxygen-glucose deprivation-induced $\mathrm{Zn}^{2+}$ accumulation and neuronal loss in hippocampal pyramidal neurons. J Neurosci 22:1273-1279.

Yuan J, Lipinski M, Degterev A (2003) Diversity in the mechanisms of neuronal cell death. Neuron 40:401-413.

Zukin RS, Jover T, Yokota H, Calderone A, Simionescu M, Lau C-Y (2004) Molecular and cellular mechanisms of ischemia-induced neuronal death. In: Stroke: pathophysiology, diagnosis, and management (Mohr JP, Choi DW, Grotta JC, Weir B, Wolf PA, eds), pp 829-854. Philadelphia: The Curtis Center. 